Prepared in cooperation with the Kootenai Tribe of Idaho and Bonneville Power Administration

\title{
Sediment Cores and Chemistry for the Kootenai River White Sturgeon Habitat Restoration Project, Boundary County, Idaho
}

Scientific Investigations Report 2011-5006

U.S. Department of the Interior

U.S. Geological Survey 



\section{Sediment Cores and Chemistry for the Kootenai River White Sturgeon Habitat Restoration Project, Boundary County, Idaho}

By Gary J. Barton, Rhonda J. Weakland, Ryan L. Fosness, Stephen E. Cox, and Marshall L. Williams

Prepared in cooperation with the Kootenai Tribe of Idaho and

Bonneville Power Administration

Scientific Investigations Report 2011-5006 


\section{U.S. Department of the Interior \\ KEN SALAZAR, Secretary \\ U.S. Geological Survey \\ Marcia K. McNutt, Director}

U.S. Geological Survey, Reston, Virginia: 2012

For more information on the USGS - the Federal source for science about the Earth, its natural and living resources, natural hazards, and the environment, visit http://www.usgs.gov or call 1-888-ASK-USGS

For an overview of USGS information products, including maps, imagery, and publications, visit http://www.usgs.gov/pubprod

To order this and other USGS information products, visit http://store.usgs.gov

Any use of trade, product, or firm names is for descriptive purposes only and does not imply endorsement by the U.S. Government.

Although this report is in the public domain, permission must be secured from the individual copyright owners to reproduce any copyrighted materials contained within this report.

Suggested citation:

Barton, G.J., Weakland, R.J., Fosness, R.L., Cox, S.E., and Williams, M.L., 2012, Sediment cores and chemistry for the Kootenai River White Sturgeon Habitat Restoration Project, Boundary County, Idaho: U.S. Geological Survey Scientific Investigations Report 2011-5006, 36 p. 


\section{Contents}

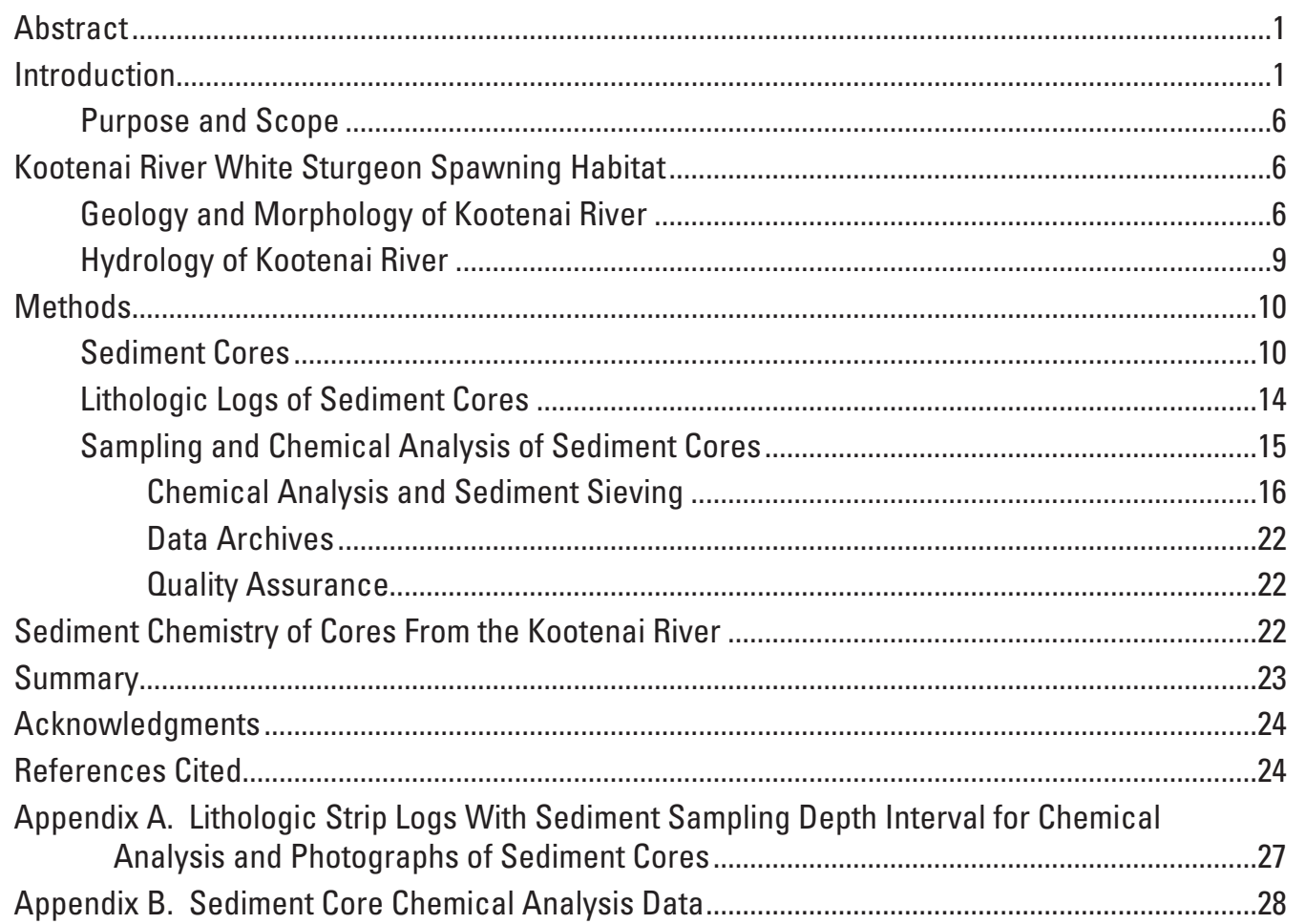




\section{Figures}

Figure 1. Map showing location of study reach in Idaho, and the Kootenai River drainage basin in Idaho, Montana, and in British Columbia, Canada

Figure 2. Maps showing location of study area, sediment-coring sites, and selected streamflow-gaging stations in the braided reach, straight reach, and meander reach, Kootenai River near Bonners Ferry, Boundary County, Idaho

Figure 3. Map showing Kootenai River basin and extent of glacial ice and glacial lakes in northern Washington, Idaho, and parts of Montana

Figure 4. Underwater video photographs showing types of substrate that form the bed of the Kootenai River near Bonners Ferry, Idaho, 2007-09

Figure 5. Photograph showing sediment-coring system on a barge on the Kootenai River, Bonners Ferry, Idaho 15

Figure 6. Photographs showing extrusion of sediments from core barrel into a 1.5-m long polyethylene core bag with a $15.2-\mathrm{cm}$ inside diameter, Kootenai River near Bonners Ferry, Idaho

Figure 7. Photograph showing macroscopic view of sediment sampled from a core collected from the Kootenai River near Bonners Ferry, Idaho

\section{Tables}

Table 1. Summary of streamflow-gaging stations on the Kootenai River near Bonners Ferry, Idaho

Table 2. Sediment cores and sediment chemistry samples collected by the U.S. Geological Survey and Idaho Department of Transportation in the Kootenai River near Bonners Ferry, Idaho

Table 3. Select polynuclear aromatic hydrocarbons, total polychlorinated biphenyls, and total organic carbon concentrations and sediment-particle sizes in sediment samples collected from cores at the Kootenai River near Bonners Ferry, Idaho, June-July 2007, and sediment-quality guidelines. 


\section{Conversion Factors, Datums, and Abbreviations and Acronyms}

Conversion Factors

\begin{tabular}{lcl}
\hline \multicolumn{1}{c}{ Multiply } & \multicolumn{1}{c}{ By } & \multicolumn{1}{c}{ To obtain } \\
\hline centimeter $(\mathrm{cm})$ & 0.06102 & inch (in.) \\
cubic meter per second $\left(\mathrm{m}^{3} / \mathrm{s}\right)$ & 70.07 & acre-foot per day (acre-ft/d) \\
cubic meter per second $\left(\mathrm{m}^{3} / \mathrm{s}\right)$ & 35.31 & cubic foot per second $(\mathrm{ft} / \mathrm{s})$ \\
gram $(\mathrm{g})$ & 0.03527 & ounce $(\mathrm{oz})$ \\
kilometer $(\mathrm{km})$ & 0.6214 & mile $(\mathrm{mi})$ \\
meter $(\mathrm{m})$ & 3.281 & foot $(\mathrm{ft})$ \\
meter per second $(\mathrm{m} / \mathrm{s})$ & 3.281 & foot per second $(\mathrm{ft} / \mathrm{s})$ \\
microgram per kilogram $(\mu \mathrm{g} / \mathrm{kg})$ & 1.0 & parts per billion $(\mathrm{ppb})$ \\
millimeter $(\mathrm{mm})$ & 0.03937 & inch (in.) \\
square meter $\left(\mathrm{m}^{2}\right)$ & 10.76 & square foot $\left(\mathrm{ft}{ }^{2}\right)$ \\
\hline
\end{tabular}

Pressure: 1 Pascal $(\mathrm{Pa})=1 \mathrm{~N} / \mathrm{m}^{2}=6.895 \mathrm{kPa}$

Temperature in degrees Celsius $\left({ }^{\circ} \mathrm{C}\right)$ may be converted to degrees Fahrenheit $\left({ }^{\circ} \mathrm{F}\right)$ as follows:

$$
{ }^{\circ} \mathrm{F}=\left(1.8 \mathrm{x}^{\circ} \mathrm{C}\right)+32 \text {. }
$$

\section{Datums}

Vertical coordinate information is referenced to the North American Vertical Datum of 1988 (NAVD 88).

Horizontal coordinate information is referenced to the North American Datum of 1983 (NAD 83), Idaho Transverse Mercator - North American Datum 1983/1998 Idaho West, in meters. 


$\begin{array}{ll}\text { Abbreviations and Acronyms } \\ \text { FRAR } & \text { Free Run Aquatic Research } \\ \text { GPS } & \text { Global Positioning System } \\ \text { ID } & \text { inside diameter } \\ \text { KTOI } & \text { Kootenai Tribe of Idaho } \\ \text { LiDAR } & \text { Light-Detecting Radar } \\ \text { MD_SWMS } & \text { Multidimensional Surface-Water Modeling System } \\ \text { NWIS } & \text { National Water Information System } \\ \text { NWOL } & \text { National Water Quality Laboratory } \\ \text { PAH } & \text { polynuclear aromatic hydrocarbon } \\ \text { PCB } & \text { polychlorinated biphenyls } \\ \text { PVC } & \text { polyvinyl chloride } \\ \text { RKM } & \text { river kilometer } \\ \text { SRM } & \text { standard reference material } \\ \text { TOC } & \text { total organic carbon } \\ \text { USGS } & \text { U.S. Geological Survey }\end{array}$




\title{
Sediment Cores and Chemistry for the Kootenai River White Sturgeon Habitat Restoration Project, Boundary County, Idaho
}

\author{
By Gary J. Barton, Rhonda J. Weakland, Ryan L. Fosness, Stephen E. Cox, and Marshall L. Williams
}

\begin{abstract}
The Kootenai Tribe of Idaho, in cooperation with local, State, Federal, and Canadian agency co-managers and scientists, is assessing the feasibility of a Kootenai River habitat restoration project in Boundary County, Idaho. This project is oriented toward recovery of the endangered Kootenai River white sturgeon (Acipenser transmontanus) population, and simultaneously targets habitat-based recovery of other native river biota. Projects currently (2010) under consideration include modifying the channel and flood plain, installing in-stream structures, and creating wetlands to improve the physical and biological functions of the ecosystem. River restoration is a complex undertaking that requires a thorough understanding of the river. To assist in evaluating the feasibility of this endeavor, the U.S. Geological Survey collected and analyzed the physical and chemical nature of sediment cores collected at 24 locations in the river. Core depths ranged from 4.6 to 15.2 meters; 21 cores reached a depth of 15.2 meters. The sediment was screened for the presence of chemical constituents that could have harmful effects if released during restoration activities. The analysis shows that concentrations of harmful chemical constituents do not exceed guideline limits that were published by the U.S. Army Corps of Engineers in 2006.
\end{abstract}

\section{Introduction}

The endangered Kootenai River white sturgeon (Acipenser transmontanus) is a naturally landlocked, locally adapted population that has been isolated since the last glacial age, approximately 10,000 years ago. The Kootenai River white sturgeon has long been, and continues to be, a culturally significant species to the Kootenai Tribe.

Since 1931, the Kootenai River white sturgeon spawning habitat in the Upper Columbia Basin was altered after construction of dams including Libby Dam in Montana in 1972 (fig. 1). Construction of dikes and the drainage of wetlands prior to the 1960s, as well as changes in nutrient availability that support the ecosystems also have affected the spawning habitat. One or more of these alterations are thought to be responsible for the recruitment failure of the Kootenai River white sturgeon for more than 3 decades (U.S. Fish and Wildlife Service, 2006). Recruitment occurs when a spawning event produces juvenile fish that survive to create a new year-class of fish in sufficient numbers to maintain the fish population.

The Kootenai Tribe of Idaho (KTOI), in cooperation with local, state, Federal, and Canadian agency co-managers and scientists, is assessing the feasibility of a Kootenai River habitat restoration project in Boundary County, Idaho. This project is oriented toward recovery of the endangered Kootenai River white sturgeon population, and simultaneously targets habitat-based recovery of other native river biota. Some projects under consideration include modifying the channel and flood plain, installing in-stream structures, and creating wetlands adjacent to the river to improve the physical and biological functions of the ecosystem (River Design Group, Inc., 2009). These actions may involve the dredging and moving of sediment, which could cause the migration or release of sequestered chemical constituents that could have a negative effect on the ecosystem. The regulatory community requires a stepwise procedure for determining whether or not contaminants are present in the sediment and if any concentrations exceed sediment-quality guidelines (U.S. Army Corps of Engineers and others, 2006) prior to any disturbance of river sediment during habitat restoration. To that end, in 2007 the KTOI contracted the coring of sediment beneath the Kootenai River from the upstream end of the braided reach at river kilometer (RKM) 257 to 0.2 kilometers upstream of Shorty's Island at RKM 131.9 (fig. 2). The KTOI requested that the U.S. Geological Survey (USGS) help plan the sediment coring, oversee coring operations, log the cores, and sample sediments in each core for chemical analysis. The KTOI also contracted with Free Run Aquatic Research (FRAR), Hayden, Idaho, to help plan sampling of sediment from cores and subsequent chemical analysis. 


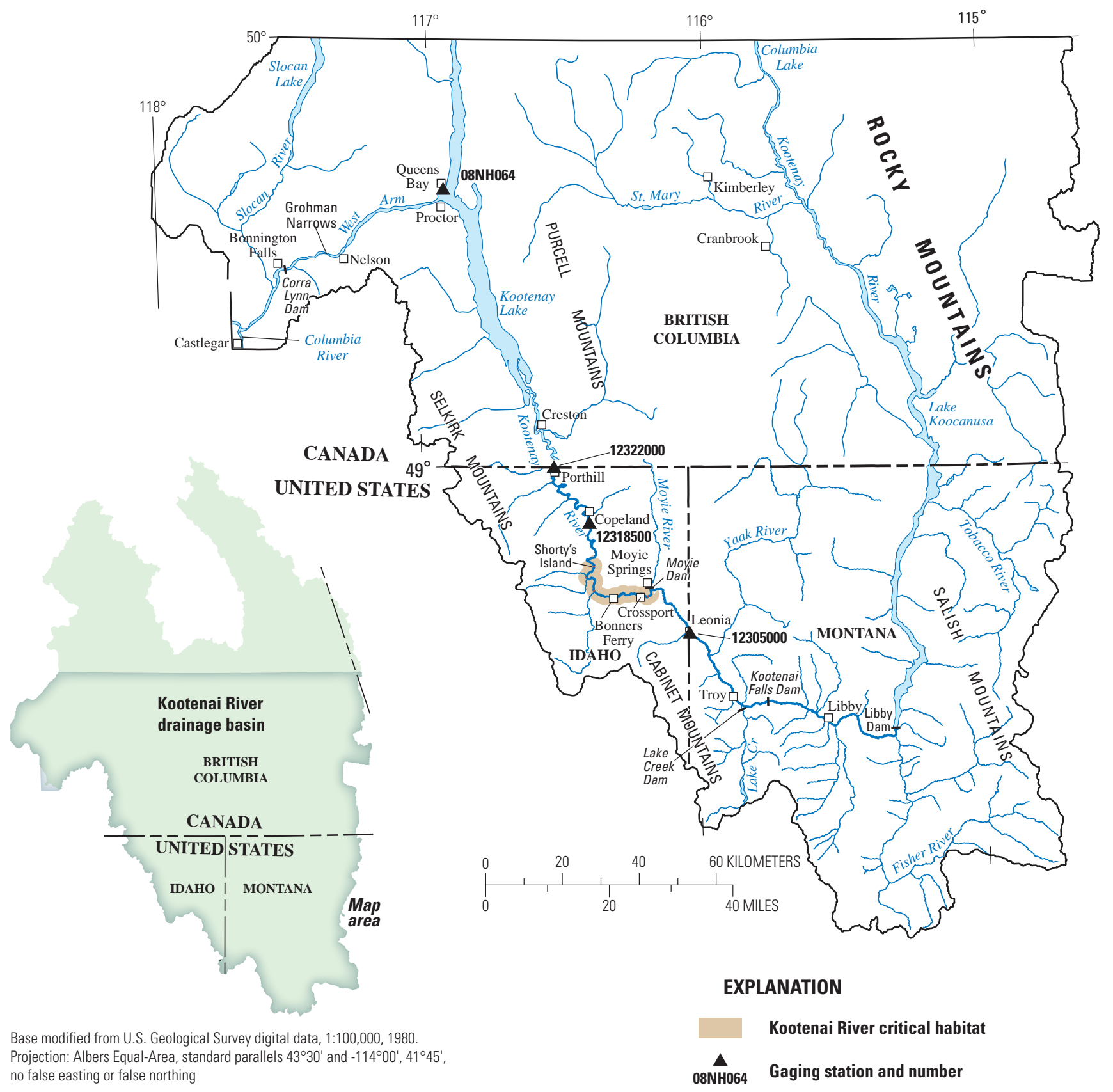

Figure 1. Location of study reach in Idaho, and the Kootenai River drainage basin in Idaho, Montana, and in British Columbia, Canada. 

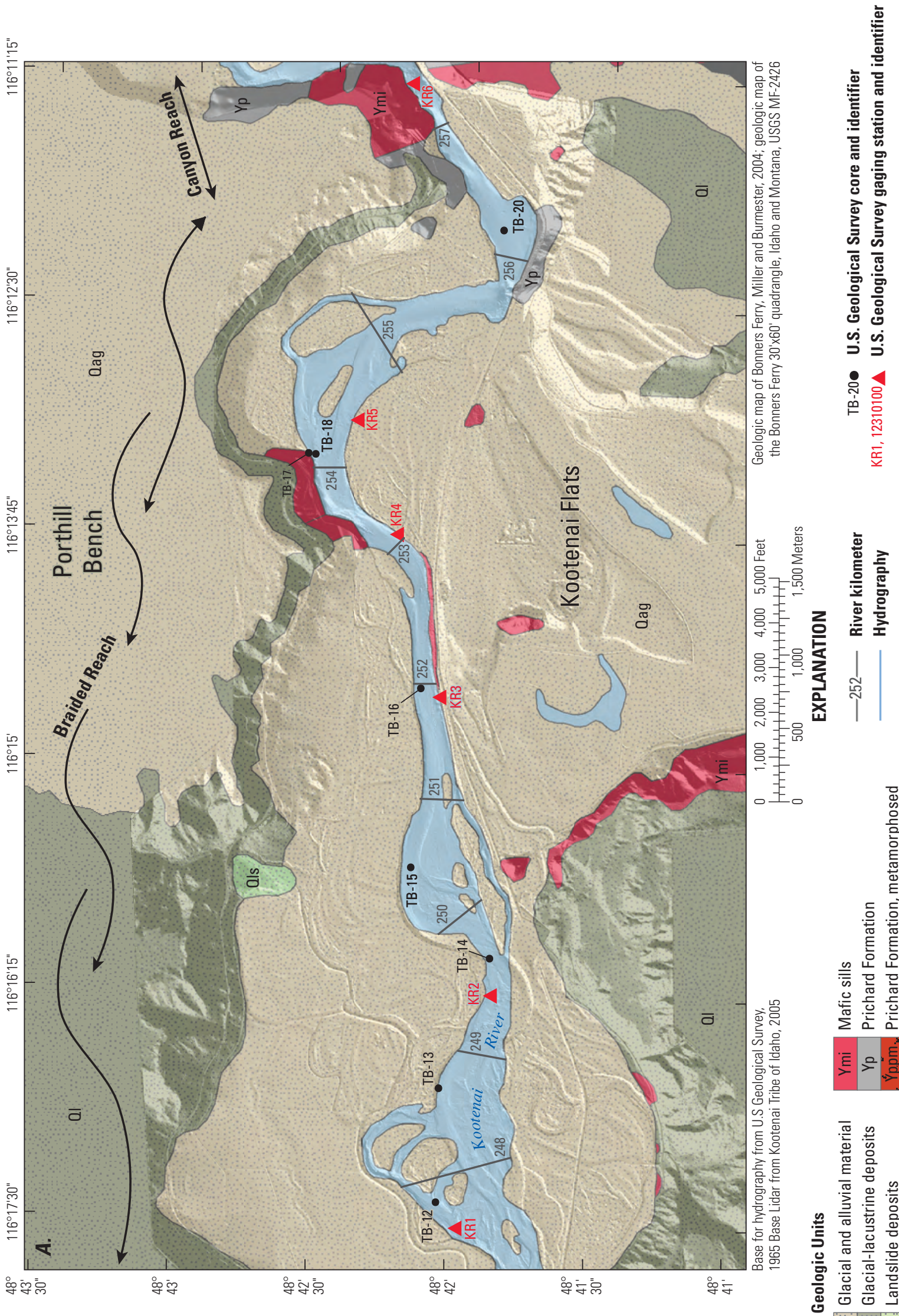

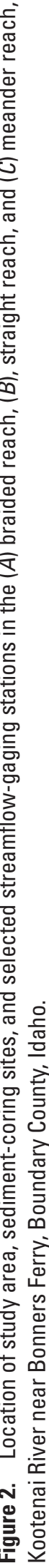




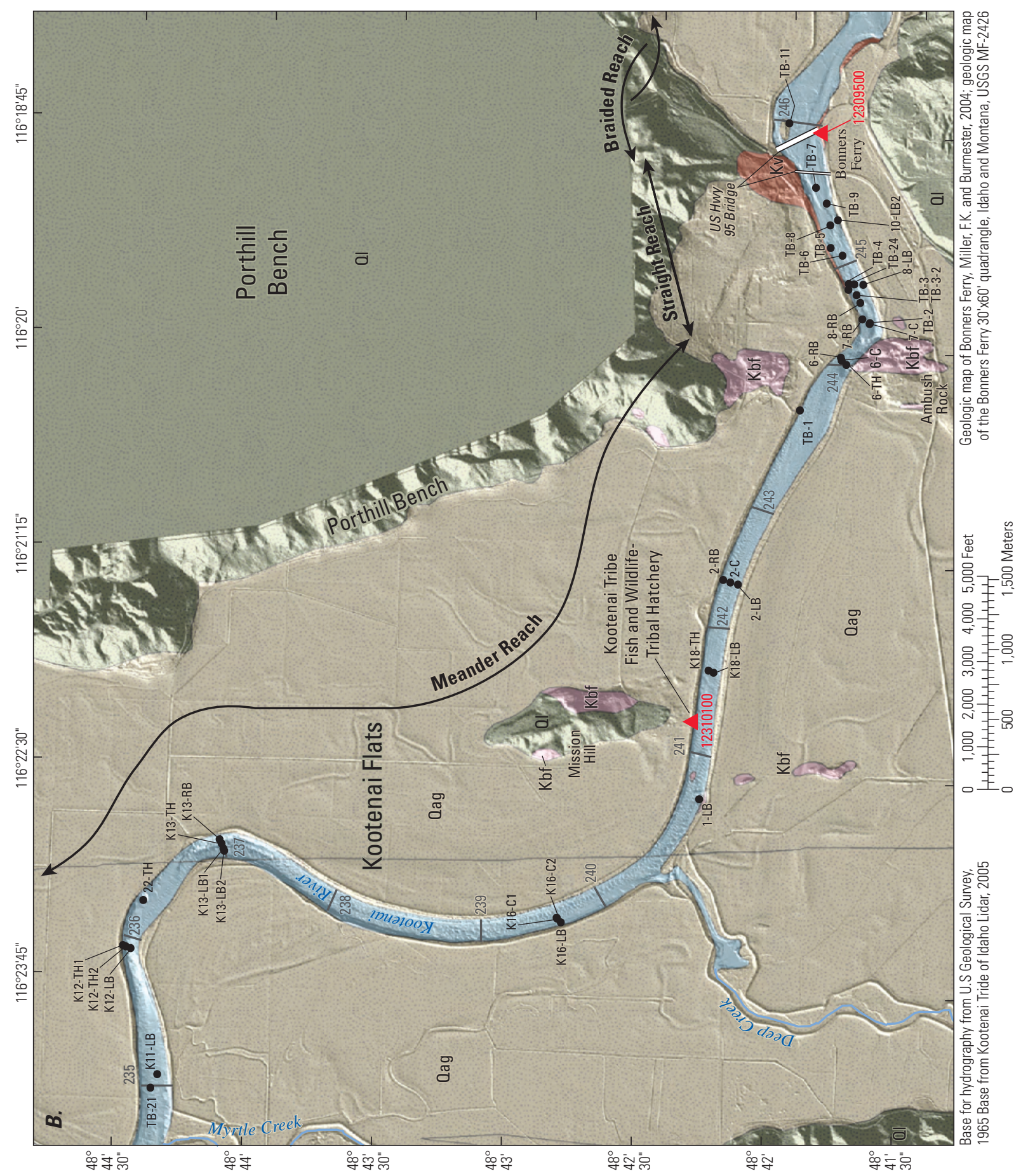

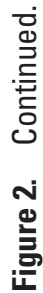




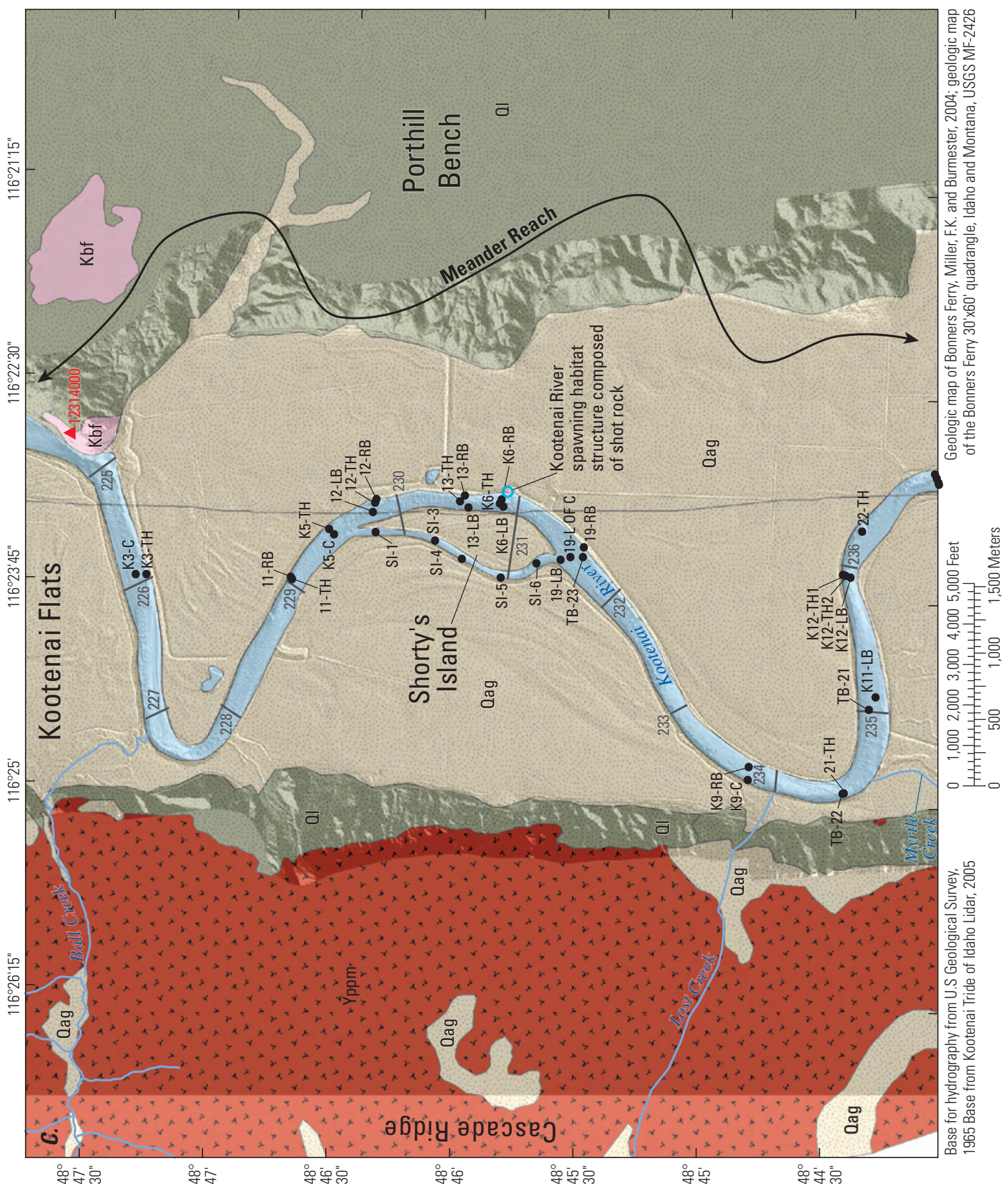

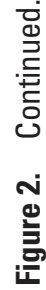




\section{Purpose and Scope}

This report provides an assessment of the riverine geology between RKMs 257 and 224.5 in the designated white sturgeon critical habitat river reach. This report complies with environmental regulatory requirements for reporting the results of screening done to identify specific chemical constituents within the sediment that have the potential to affect the ecosystem if released during restoration activities. These basic data and interpretations will help to facilitate restoration planning and help assess the feasibility of potential habitat redesign considerations.

\section{Kootenai River White Sturgeon Spawning Habitat}

White sturgeon egg collection and telemetry data collected by the Idaho Department of Fish and Game indicates that most spawning on the Kootenai River currently is within the meander reach between RKMs 240 and 228 (figs. 2B and $\underline{2 C}$ ). Some spawning activity, however, has been monitored near Bonners Ferry, Idaho, in the straight reach between RKMs 245.7 and 245.1 (Paragamian and others, 2002; Barton and others, 2005, fig. 3). A series of research investigations determined that white sturgeon were spawning over unsuitable incubation and rearing habitat (sand) and survival of eggs and larvae was negligible (Paragamian and others, 2002). Sedimentation has been presented as a likely source of mortality for white sturgeon embryos in the Kootenai River (Paragamian and others, 1995, 1996, 1997, 1998, 1999, 2002; Kock and others, 2006). Kock and others (2006) showed that incubating white sturgeon embryos are highly sensitive to sediment cover. Various combinations of sediment depth and sediment cover duration resulted in severely reduced embryo survival. After 9 days, sediment depths of only $5 \mathrm{~mm}$ reduced survival to less than 20 percent of uncovered controls. These results indicate that Kootenai River white sturgeon embryos experience high mortality rates in their current spawning habitat, which is characterized by a fine sand substrate (Barton and others, 2006; McDonald and others, 2006). Habitat suitability curves developed for white sturgeon in the Lower Columbia River (Parsley and Beckman, 1994) show that sturgeon spawn over gravel and cobble to provide a stable egg attachment site for developing eggs that will become new fish year classes.

\section{Geology and Morphology of Kootenai River}

The present course of the Kootenai River in the study area is controlled by Precambrian and Cretaceous bedrock at several locations and by Quaternary lacustrine clay (fig. 2). The river courses through valley-fill sediment composed of interbedded silts and clays of glaciolacustrine origin and sands, gravels, and cobbles of fluvial and glaciofluvial origin. Most gravels and sands in the study area were deposited during the cyclic retreat of the Purcell Trench Lobe about 14,000 years ago (fig. 3; Atwater, 1986, pl. 1; Buchanan, 1989). Additionally, some gravels and cobbles occur in the alluvial fan deposits associated with tributaries flowing off the flank of the Selkirk Mountains (fig. 1). Lacustrine clays and silts are common in the Kootenai Flats (fig. 2B and 2C) and along the flanks of the mountains bordering the valley. As the Purcell Trench Lobe retreated to the north, a glacial Kootenay Lake was formed behind the ice dam and finegrained sediments consisting of silts and clays were deposited in the glacial lake in Idaho and British Columbia. These clays and silts often are underlain by sands, gravels, and cobbles associated with the retreat of the Purcell Trench Lobe. J-U-B Engineers, Inc. (1998) reported that the lacustrine clay tends to thicken in the downstream direction.

The Kootenai River in the upper part of the study area is a braided reach that actively changes course and flows over gravel and cobbles, some sand, and a few areas of bedrock (fig. 4). This 11.1-km reach extends from RKM 257 downstream of the Moyie River to RKM 245.9 at Bonners Ferry. This reach is mostly a multi-threaded channel; about $3 \mathrm{~km}$ of the reach is a single-threaded channel (figs. $2 \mathrm{~A}$ and $\underline{2 B}$ ). Many gravel bars, sloughs, and islands are in the channel and many of the side sloughs are dry during periods of low flow. Scour pools form at two locations upstream of Crossport where bedrock outcrops along the river and water depths in the pools exceed $15 \mathrm{~m}$; bedrock rubble in these locations is scattered on the riverbed. When streamflow is $850 \mathrm{~m}^{3} / \mathrm{s}$ $\left(30,000 \mathrm{ft}^{3} / \mathrm{s}\right)$, the average depth of water in the braided reach is about $3 \mathrm{~m}$; depths generally are less than other parts of the study area. The average and maximum velocities are about 1.2 and $2.8 \mathrm{~m} / \mathrm{s}$, respectively (Barton and others, 2009).

A short straight reach downstream of the braided reach is between RKMs 245.9 and 244.5 and forms a transition zone between the braided reach and the meander reach (fig. 2B; Tetra Tech, Inc., 2003). The river substrate in the straight reach consists of gravel, sand, and traces of cobble and bedrock. This bedrock outcrops at several small areas along the right bank. A large outcrop with a deep scour hole (known as Ambush Rock) is along the left bank (fig. 4). The channel in this area is single threaded except during low flow when gravel bars are exposed in the upstream half of the reach. 


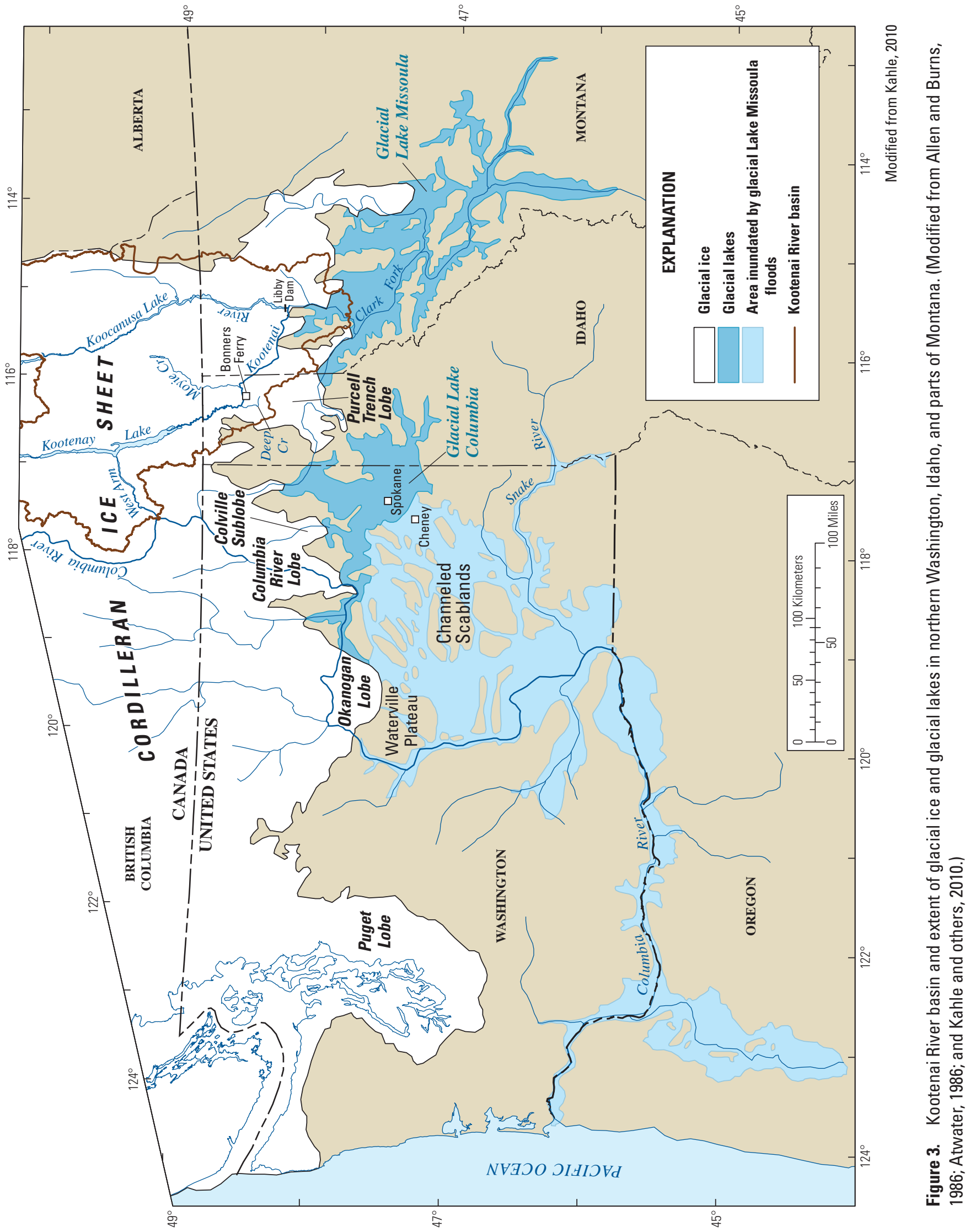



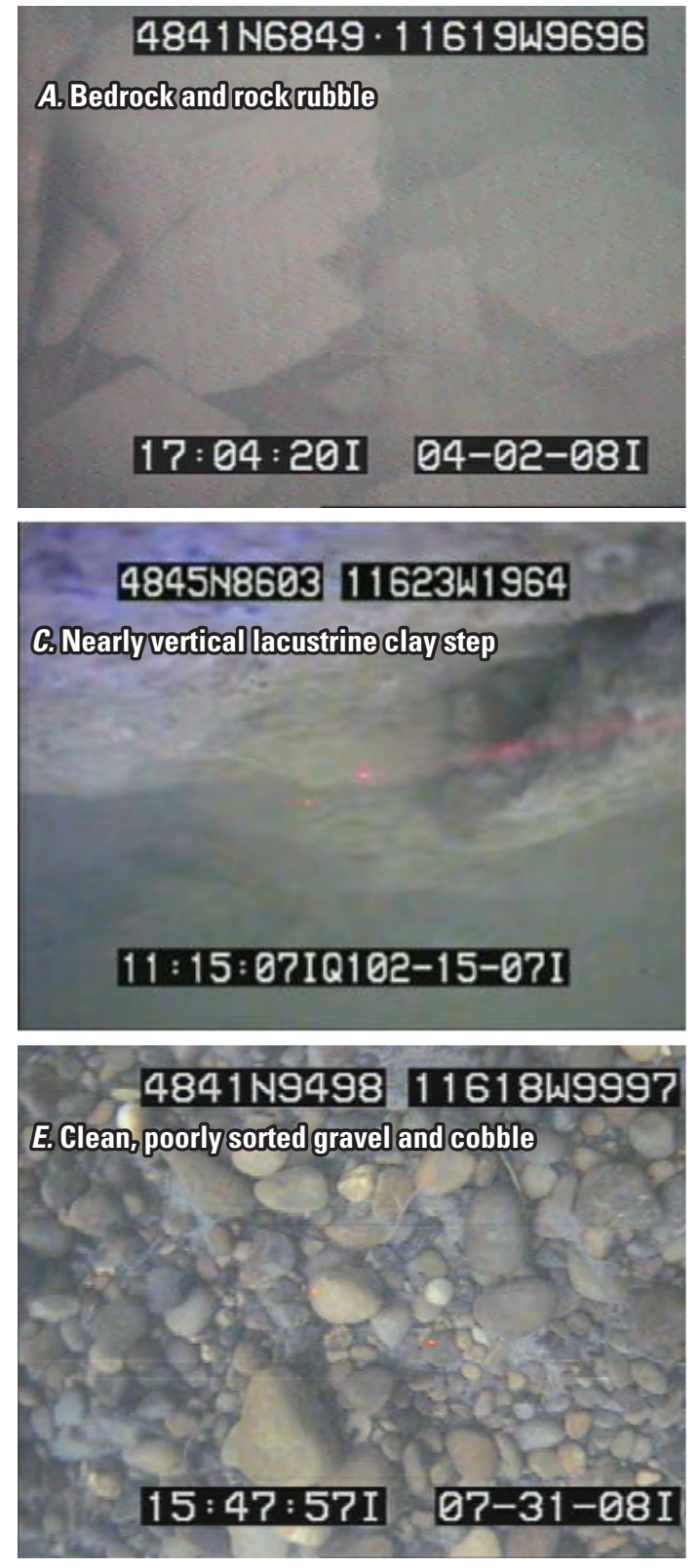

\section{$4845 \mathrm{~N} 9052 \cdot 11623 \mathrm{~W} 2145$}

G.Sand forming dunesand ripples
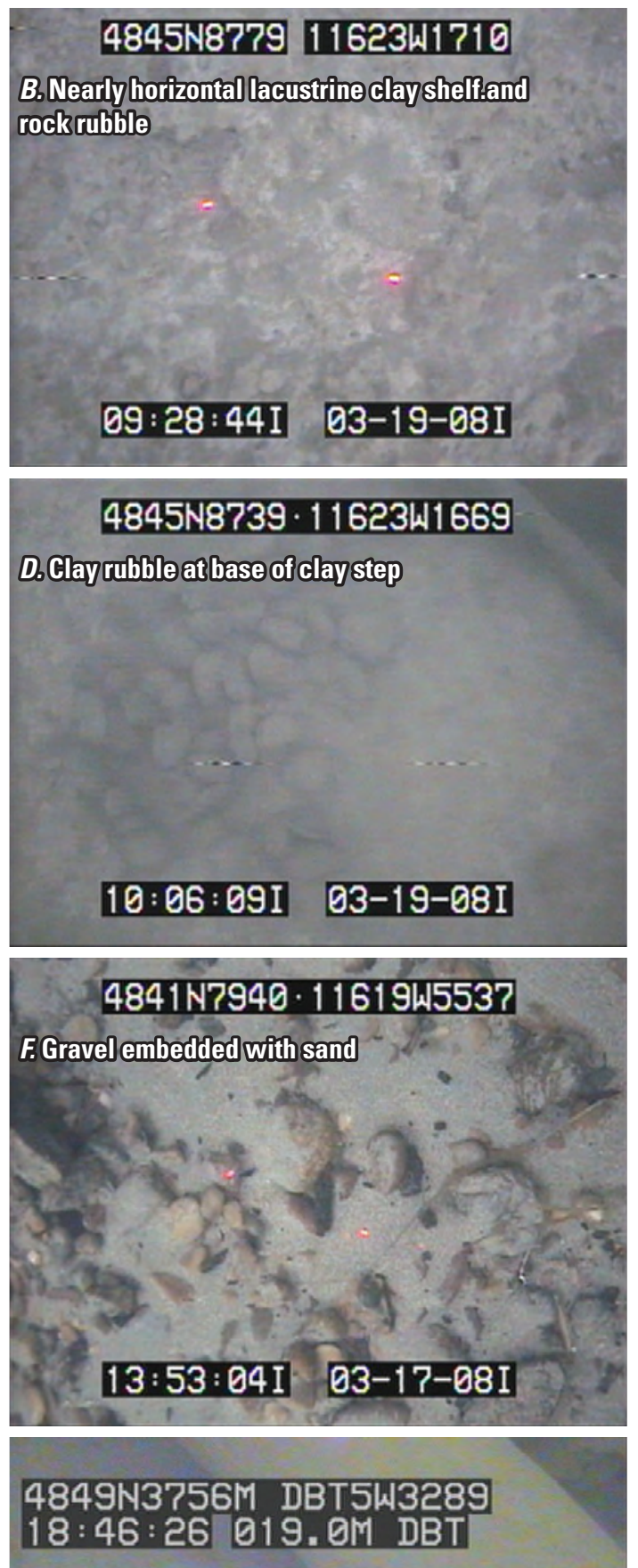

H. Logsend oothep organio debris

\section{1:19:15IQ102-15-07I}

\section{3-14-09I $11: 44: 31$ I}

Figure 4. Underwater video photographs showing types of substrate that form the bed of the Kootenai River near Bonners Ferry, Idaho, 2007-09. Information on photographs includes coordinates as North American Datum of 1983, date, time, and (H) shows depth to riverbed in meters (DBT). Laser scale is 10.5 centimeters. (Underwater video photographs taken by Marshall Williams, U.S. Geological Survey, dates indicated in photographs.) 
When streamflow is $850 \mathrm{~m}^{3} / \mathrm{s}$, the average and maximum depth and velocity in the straight reach is about 4 and $23 \mathrm{~m}$ and 0.9 and $1.3 \mathrm{~m} / \mathrm{s}$, respectively (Barton and others, 2009).

The meander reach, downstream of the straight reach, extends from RKM 244.5 to Kootenay Lake and for this study extends downstream to RKM 224.5 (fig. 2C). The study reach is mostly a sand riverbed that is entrenched in the lacustrine clay valley. The sand forms a mobile streambed consisting mostly of dune bedforms with amplitudes that sometimes are greater than $1 \mathrm{~m}$ (Barton and others, 2006). Lacustrine clay and silt generally form steep steps and flat lying shelves mostly in the meander bends (fig. 4). Clay rubble with the appearance of gravel and cobble is at the base of the clay steps. At a few locations, bedrock outcrops in the channel and along the riverbank with rock rubble on the riverbed at the base of outcrops. Small patches of gravel and cobble lag deposits form the riverbed downstream of the mouth of some tributaries and near Shorty's Island. Additionally, some small isolated gravel lenses are buried by sand in the meander reach (Barton, 2004). Riprap consisting of shot rock, boulders, and cobble has been placed on the dikes in select locations for armoring. Some riprap has rolled down the riverbank and into the channel. When streamflow is $850 \mathrm{~m}^{3} / \mathrm{s}$, the average and maximum depth and velocity in the meander reach are about 7 and $23 \mathrm{~m}$ and 0.6 and $1.1 \mathrm{~m} / \mathrm{s}$, respectively (Barton and others, 2009).

\section{Hydrology of Kootenai River}

The historical natural flow of the Kootenai River followed the annual hydrologic cycle. Average annual precipitation at Bonners Ferry for 1907-2008 is $56 \mathrm{~cm}$ with a mean monthly minimum of $2.3 \mathrm{~cm}$ in July and mean monthly maximum of $7.8 \mathrm{~cm}$ in December; the autumn and winter months are the wettest and summer months are the driest. The greatest discharge during each year was generally caused by melting of snow at high altitudes. As each spring approached, snowmelt caused the streamflow to increase until the maximum flow was reached, usually in June. Thereafter, the flow generally would decrease with minor fluctuations until the following spring. The tributaries follow the same general flow pattern but with much less predictability (Dion and Whitehead, 1973).

Based on historical data (1966-71) collected at the Copeland gaging station (12318500; fig. 1), during the pre-Libby Dam era, the median annual peak spring-summer streamflow was about $2,240 \mathrm{~m}^{3} / \mathrm{s}$. The annual peak springsummer streamflow during the beginning of the Libby Dam era, 1970s through 1980s, was several times less than during the pre-Libby Dam era with much higher winter flows (Barton, 2004). The altered hydrology created by Libby Dam is suspected as part of the problem in sturgeon recruitment, and is the focus of many studies over the past several decades.

Since the mid-1990s, the U.S. Fish and Wildlife Service requested that Kootenai River streamflows be increased during white sturgeon spawning in May and June in an attempt to help re-establish hydrologic regimes that would more closely approach historical spawning conditions to benefit recruitment. To achieve this, Kootenai River streamflows are augmented with additional release of water from Libby Dam; however, the median streamflow during spawning season is about one-half that of the pre-Libby Dam era (Barton and others, 2009). A summary of streamflow gaging stations on the Kootenai River near Bonners Ferry, Idaho, is provided in table 1. The USGS has operated several stage gages in the braided reach since 2006.

Table 1. Summary of streamflow-gaging stations on the Kootenai River near Bonners Ferry, Idaho.

[A bbreviations: RKM, river kilometer; S, stage; T, temperature; Q, discharge; V, stream velocity; USGS, U.S. Geological Survey]

\begin{tabular}{|c|c|c|c|c|c|}
\hline $\begin{array}{l}\text { Station } \\
\text { No. }\end{array}$ & Station name & Agency & RKM & $\begin{array}{c}\text { Data } \\
\text { parameters }\end{array}$ & Period of record \\
\hline KR1 & KootR_abv_Watint & USGS & 247.7 & $\mathrm{~S}, \mathrm{~T}$ & 2006-present (fragmentary) \\
\hline KR3 & KootR_at_Crossport & USGS & 251.9 & $\mathrm{~S}, \mathrm{~T}$ & 2006-present (fragmentary) \\
\hline KR4 & KootR_nr_Crossport & USGS & 253.1 & $\mathrm{~S}, \mathrm{~T}$ & 2006-2007 (fragmentary) \\
\hline 12309500 & $\begin{array}{l}\text { Kootenai River at Tribal Hatchery, near } \\
\text { Bonners Ferry, Idaho }\end{array}$ & USGS & 245.9 & $\mathrm{~S}$ & October 2002-present \\
\hline 12310100 & Kootenai River at Bonners Ferry, Idaho & USGS & 241.2 & $\mathrm{~S}, \mathrm{Q}, \mathrm{V}, \mathrm{T}$ & May-October 1904, October 1927-present \\
\hline 12314000 & $\begin{array}{l}\text { Kootenai River at Klockmann Ranch, near } \\
\text { Bonners Ferry, Idaho }\end{array}$ & USGS & 225.4 & $\mathrm{~S}$ & $\begin{array}{l}\text { May 1928-Present (fragmentary prior to April } \\
\text { 1930, partial record year 2006) }\end{array}$ \\
\hline
\end{tabular}


One of the most important components for successful wetland development is the evaluation of water availability and control. These basic data are needed for designing sustainable wetland habit; therefore, water levels from wells, Kootenai River stage for low streamflow, and mean annual peak and record high streamflow during the Libby Dam era are included with the geohydrologic sections. Kootenay Lake in British Columbia, Canada, creates backwater conditions in the Kootenai River that can extend several kilometers upstream of Bonners Ferry into the braided reach (fig. 2A). The extent of backwater is a function of river flows upstream of the backwater reach and Kootenay Lake levels. During periods of low streamflow, backwater conditions diminish and free-flowing water may extend a few kilometers downstream of RKM 245.9 in the straight reach. A detailed analysis of the location of transition between the free-flowing river and backwater under a range of streamflow conditions is presented in Berenbrock (2005).

The USGS studied stage of the Kootenai River and water levels from wells in the Kootenai Flats between the Moyie River and Porthill, Idaho, from 1928 to 1958 and results of the studies are presented in several informal progress reports prepared during that period (Newell, 1933; U.S. Geological Survey, 1966). Prior to the 1931 construction of Corra Linn Dam in British Columbia, Canada, the USGS began a study concerning the effects of Kootenay Lake and Kootenai River regulation on the groundwater system of the Kootenai Flats. During this study, 300 shallow wells were installed to monitor the effect of the impending change in river stage on the groundwater system. Prior to the commencement of operations at Libby Dam in March 1972, the USGS installed and measured water levels in wells in the Kootenai Flats area during 1971 (Dion and Whitehead, 1973).

Recharge to the valley-fill aquifer system in the Kootenai Flats is mainly by downward percolation of precipitation and snowmelt, groundwater flow from adjacent upland areas, upward leakage of groundwater from bedrock beneath the valley-fill sediments, and seepage from the Kootenai River and its tributaries. Groundwater beneath the Kootenai Flats is locally shallow. The valley-fill aquifer system contains considerable amounts of fine-grained sediments and coarse grained sediment such as gravel. Due to the PleistoceneHolocene glaciations, however, the sediment composition in the study area can vary laterally over short distances. Groundwater moves slowly through the glaciofluvial and glaciolacustrine aquifer system to the closest points of discharge, namely, agricultural drainage ditches, stream and river channels, and areas of evapotranspiration. Drainage districts were formed throughout the Kootenai Flats in the early $20^{\text {th }}$ century. These drainage districts have focused on intercepting groundwater and lowering the water table using permanent or temporary drainage ditches in fields to support agricultural activities. This water is conveyed in open ditches to a pumping plant and then is pumped to the river (U.S. Army Corps of Engineers, 2005).

During long periods of low river stage in the Kootenai River, the water table slopes downward from the foothills all the way to the river channel where water seeps from the aquifer into the river. During long periods of high river stage, the water table slopes downward and away from the river channel and from the surrounding foothills. Near the river channel, the aquifer is partly recharged by seepage from the river during periods of high river stage. Dion and Whitehead (1973) reported that an examination of water levels from wells installed in 1930 indicates that the effects of aquifer recharge from the Kootenai River are dampened with distance and cannot be detected more than about $900 \mathrm{~m}$ from the river. Under pre-Libby Dam conditions, the highest water levels in wells away from the river occurred in spring, immediately following the period of greatest recharge, and lowest water levels occurred in autumn following the period of least recharge. Dion and Whitehead (1973) also reported that the timing and magnitude of these relations during the Libby Dam era were dependent on the regulation of streamflow in the river. Operation of Libby Dam changed long-established patterns of river stage and groundwater-level fluctuation. Regulated river levels and higher than natural levels during winter low streamflow seasons diminish the opportunity for subdrainage from the surrounding agricultural lands to the deep channel of the Kootenai River. Water levels in wells away from the river are influenced primarily by local groundwater recharge and discharge, which includes melting of the snowpack on the Kootenai Flats, discharge of tributary streams carrying low-altitude snowmelt, agricultural drainage ditches, water-supply wells, and evapotranspiration.

\section{Methods}

Methods used in this study include sediment coring, lithologic logging of sediment cores, sampling and chemical analysis of sediment cores, riverbed sediment facies mapping, and multibeam echosounder mapping.

\section{Sediment Cores}

Sediment cores were collected at 24 locations during June and July 2007 (fig. 2; table 2). Core depths ranged from 4.6 to $15.2 \mathrm{~m}$ with 21 cores reaching a depth of $15.2 \mathrm{~m}$. A maximum coring depth of $15.2 \mathrm{~m}$ below the riverbed was established for the coring program because channel modifications under consideration are not likely to extend to depths much greater than $15.2 \mathrm{~m}$ (Dave Rosgen, Wildland Hydrology, written commun., 2007). Sediment cores were bored using a $6 \times 12 \mathrm{~m}$ drilling barge operated by Crux Subsurface, Inc., of Spokane, Washington. 
Table 2. Sediment cores and sediment chemistry samples collected by the U.S. Geological Survey and Idaho Department of Transportation in the Kootenai River near Bonners Ferry, Idaho.

[NWIS well identification No.: From U.S. Geological Survey National Water Inventory Site (NWIS) database. Abbreviations: USGS, U.S. Geological Survey; IDT, Idaho Department of Transportation; TB, test boring; RB, core collected near right bank; C, core collected near center of channel; TH, core collected near thalweg; R of C, core collected right of center of channel; L of C, core collected left of center of channel; LTH, core collected left of thalweg; RTH, core collected right of thalweg; SI, core collected in minor channel at Shorty's Island; cm, centimeter; m, meter; -, not applicable or no data]

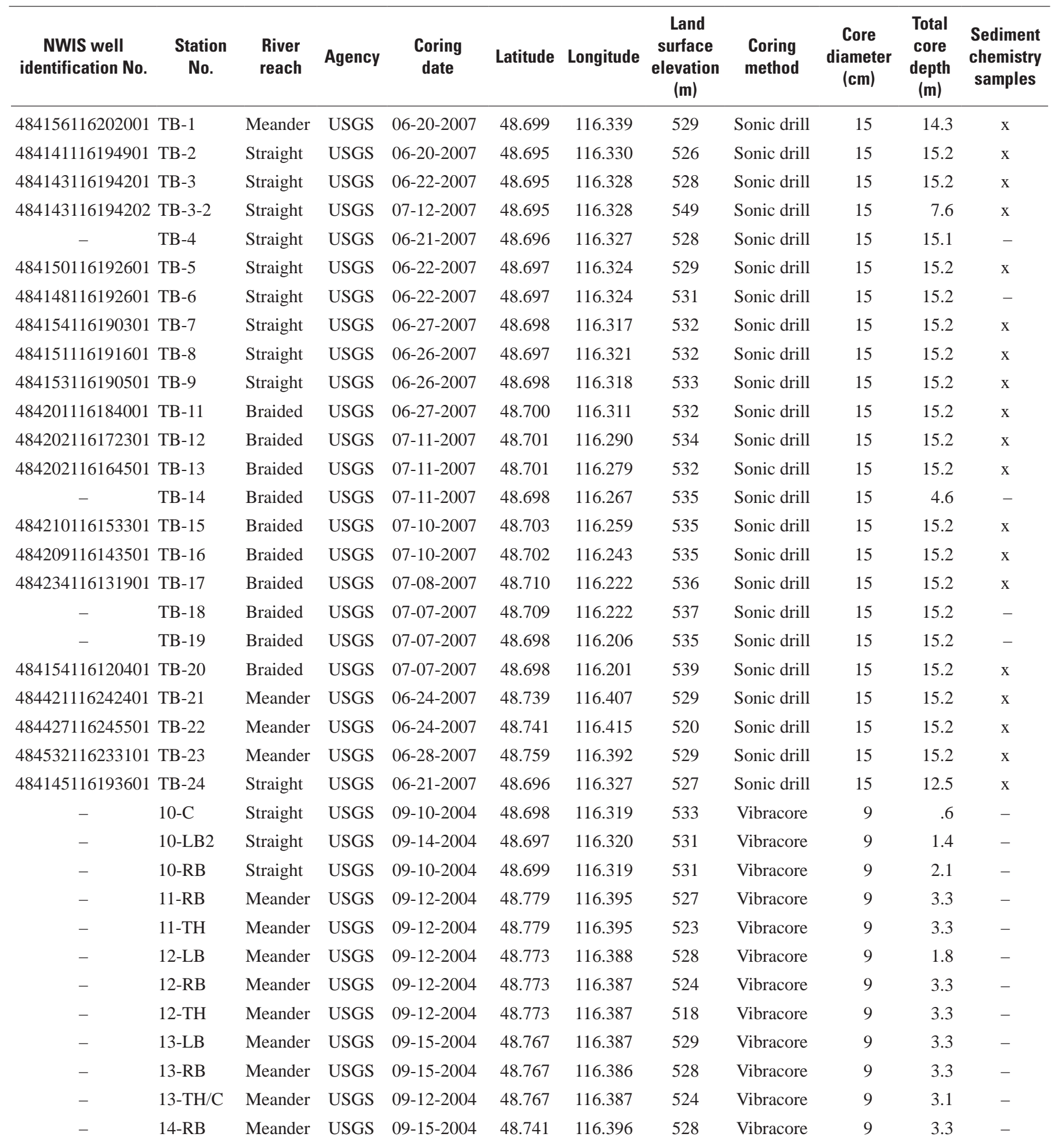


Table 2. Sediment cores and sediment chemistry samples collected by the U.S. Geological Survey and Idaho Department of Transportation in the Kootenai River near Bonners Ferry, Idaho.-Continued

[NWIS well identification No.: From U.S. Geological Survey National Water Inventory Site (NWIS) database. Abbreviations: USGS, U.S. Geological Survey; IDT, Idaho Department of Transportation; TB, test boring; RB, core collected near right bank; C, core collected near center of channel; TH, core collected near thalweg; R of C, core collected right of center of channel; L of C, core collected left of center of channel; LTH, core collected left of thalweg; RTH, core collected right of thalweg; SI, core collected in minor channel at Shorty's Island; cm, centimeter; m, meter; -, not applicable or no data]

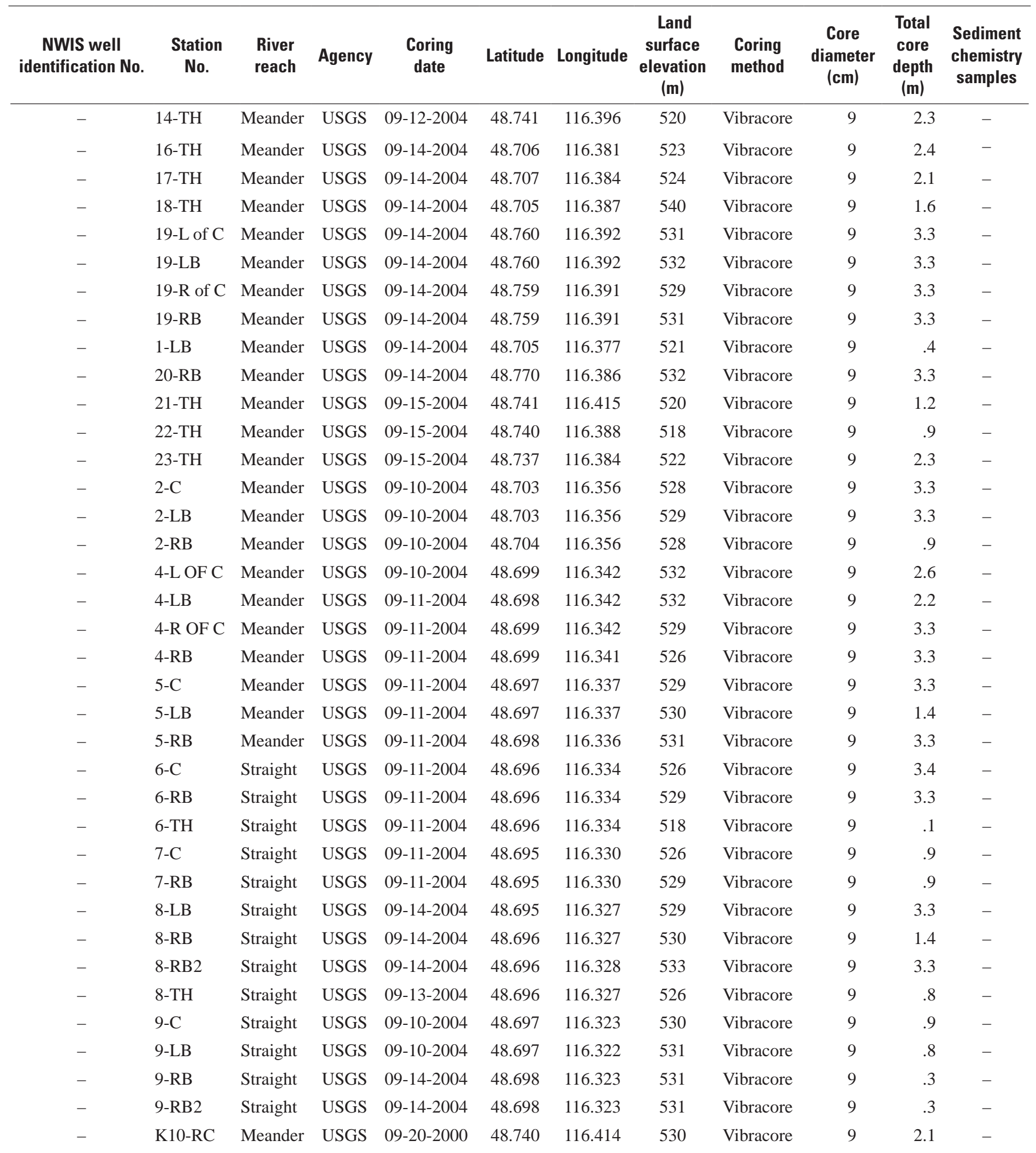


Table 2. Sediment cores and sediment chemistry samples collected by the U.S. Geological Survey and Idaho Department of Transportation in the Kootenai River near Bonners Ferry, Idaho.—Continued

[NWIS well identification No.: From U.S. Geological Survey National Water Inventory Site (NWIS) database. Abbreviations: USGS, U.S. Geological Survey; IDT, Idaho Department of Transportation; TB, test boring; RB, core collected near right bank; C, core collected near center of channel; TH, core collected near thalweg; R of C, core collected right of center of channel; L of C, core collected left of center of channel; LTH, core collected left of thalweg; RTH, core collected right of thalweg; SI, core collected in minor channel at Shorty's Island; cm, centimeter; m, meter; -, not applicable or no data]

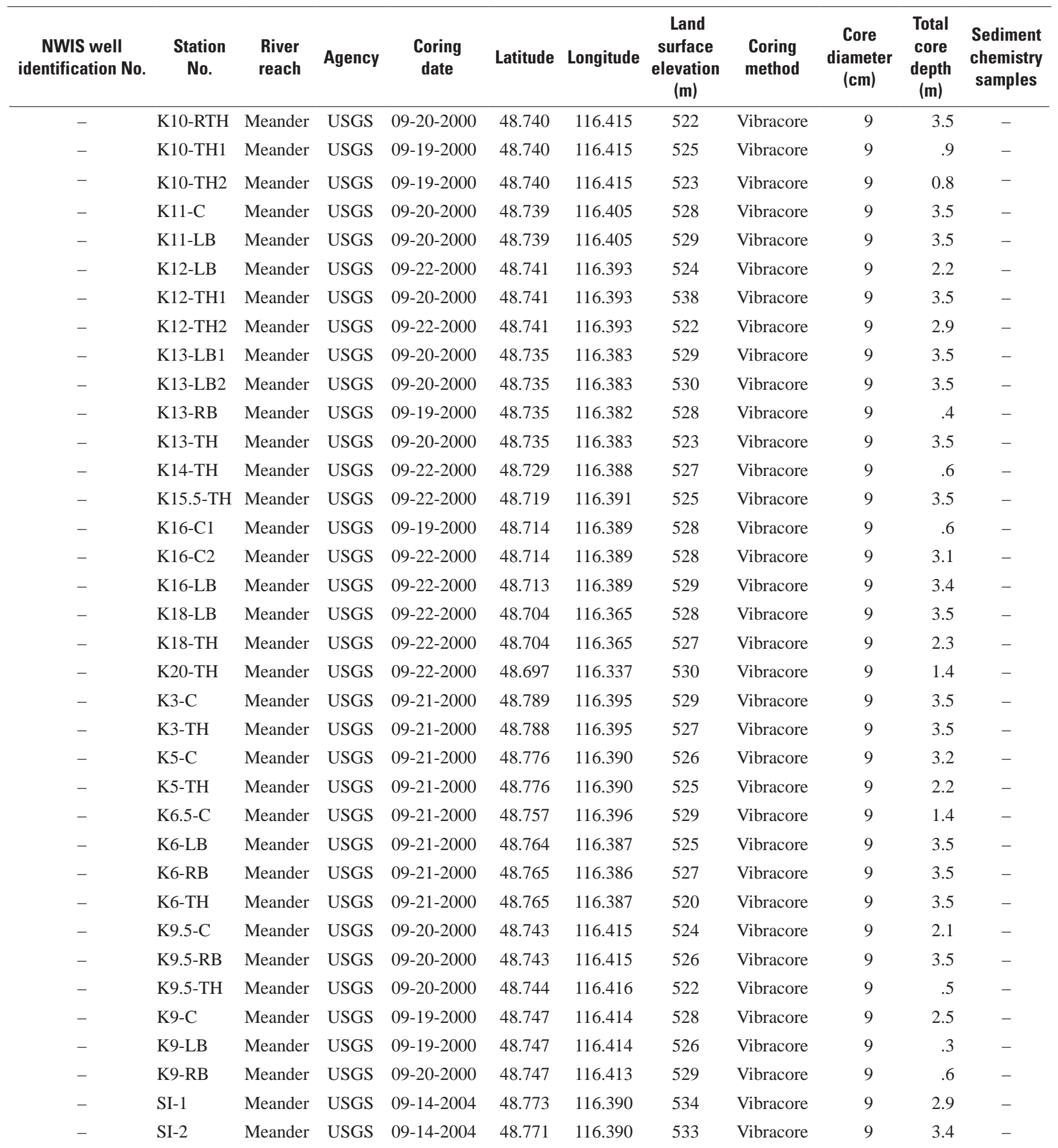


Table 2. Sediment cores and sediment chemistry samples collected by the U.S. Geological Survey and Idaho Department of Transportation in the Kootenai River near Bonners Ferry, Idaho.-Continued

[NWIS well identification No.: From U.S. Geological Survey National Water Inventory Site (NWIS) database. Abbreviations: USGS, U.S. Geological Survey; IDT, Idaho Department of Transportation; TB, test boring; RB, core collected near right bank; C, core collected near center of channel; TH, core collected near thalweg; R of C, core collected right of center of channel; L of C, core collected left of center of channel; LTH, core collected left of thalweg; RTH, core collected right of thalweg; SI, core collected in minor channel at Shorty's Island; cm, centimeter; m, meter; -, not applicable or no data]

\begin{tabular}{|c|c|c|c|c|c|c|c|c|c|c|c|}
\hline $\begin{array}{c}\text { NWIS well } \\
\text { identification No. }\end{array}$ & $\begin{array}{c}\text { Station } \\
\text { No. }\end{array}$ & $\begin{array}{l}\text { River } \\
\text { reach }\end{array}$ & Agency & $\begin{array}{l}\text { Coring } \\
\text { date }\end{array}$ & Latitude & Longitude & $\begin{array}{c}\text { Land } \\
\text { surface } \\
\text { elevation } \\
\text { (m) }\end{array}$ & $\begin{array}{l}\text { Coring } \\
\text { method }\end{array}$ & $\begin{array}{c}\text { Core } \\
\text { diameter } \\
\text { (cm) }\end{array}$ & $\begin{array}{l}\text { Total } \\
\text { core } \\
\text { depth } \\
\text { (m) }\end{array}$ & $\begin{array}{c}\text { Sediment } \\
\text { chemistry } \\
\text { samples }\end{array}$ \\
\hline- & SI-3 & Meander & USGS & 09-14-2004 & 48.769 & 116.391 & 533 & Vibracore & 9 & 2.9 & - \\
\hline- & SI-4 & Meander & USGS & 09-14-2004 & 48.767 & 116.393 & 532 & Vibracore & 9 & 1.2 & - \\
\hline- & SI-5 & Meander & USGS & 09-14-2004 & 48.764 & 116.394 & 533 & Vibracore & 9 & 1.6 & - \\
\hline- & SI-6 & Meander & USGS & 09-14-2004 & 48.762 & 116.393 & 532 & Vibracore & 9 & 1.6 & - \\
\hline- & IDT $\mathrm{DH}-2^{1}$ & Straight & IDT & 04-01-1980 & 48.699 & 116.312 & 530 & Rotary & - & 13.3 & \\
\hline - & IDT DH-3 ${ }^{1}$ & Straight & IDT & 04-01-1980 & 48.700 & 116.313 & 533 & Rotary & - & 15.1 & \\
\hline - & IDT DH-4 ${ }^{1}$ & Straight & IDT & 04-01-1980 & 48.701 & 116.314 & 539 & Rotary & - & 11.3 & \\
\hline - & IDT DH-6 ${ }^{1}$ & Straight & IDT & 04-01-1980 & 48.698 & 116.312 & 536 & Rotary & - & 30.0 & \\
\hline- & IDT DH-7 $^{1}$ & Straight & IDT & 04-01-1980 & 48.699 & 116.313 & 533 & Rotary & - & 29.9 & \\
\hline - & IDT DH-8 ${ }^{1}$ & Straight & IDT & 04-01-1980 & 48.701 & 116.314 & 534 & Rotary & - & 26.2 & \\
\hline
\end{tabular}

Site locations for the sediment cores were established by aligning sites with a conceptual river design provided by KTOI and selecting sites near bedrock that could impede realignment of the channel. The upstream and downstream extent of core site selection was based on the conceptual design for the braided and meander reaches. Substrate in this extent consisted of cobbles, gravel, sand, silt, clay, and bedrock. The spacing of the cores was not evenly distributed, but focused on key areas where examination of the geology would provide the most information. Previous core samples were collected by the USGS during 2000 and 2004 (Barton, 2004; Berenbrock and Bennett, 2005), and provided information about the geology within the meander reach and some information about the straight reach. An important goal of the 2007 coring effort was to learn more about the geology of the straight and braided reaches. Of the 24 coring sites bored in 2007, 10 sites were distributed throughout the braided reach, 10 sites were between Ambush Rock (RKM 244.5) and the U.S. Highway 95 Bridge (RKM 245.9), and 4 sites were in the meander reach between Ambush Rock and Shorty's Island. A mapping-grade global positioning system (GPS) and pusher boats were used to move the drilling barge into position for coring. Four 1-ton anchors or jack-up legs, depending on river depth, maintained the position of the barge during coring.

A track-mounted sonic drill operated by Boart Longyear of Tualatin, Oregon, was mounted on the drilling barge, and collected continuous cores of sediments beneath the riverbed (fig. 5). A 17.8-cm inside diameter (ID) override casing extended from the barge drill deck through the water column and into the sediments beneath the riverbed. A 15.2-cm ID stainless steel core barrel ranging from 1.5- to 6-m long was advanced through the bottom of the override casing to core the sediment. The override casing prevented the core hole from collapsing, and prevented river water from contacting and possibly contaminating the sediments in the core barrel. Before coring commenced at each core site, the core barrel was steam cleaned with deionized water to remove contaminants on the core barrel and to avoid crosscontamination between coring sites. Drilling fluids were not used during the sediment coring to avoid introducing contaminants into sediments in the core barrel. Sediments in the core barrel were extruded by gravity and vibration into a $2 \mathrm{~mm}$ thick, 15.2-cm ID and $1.5 \mathrm{~m}$ long polyethylene core bag (fig. 6). The core bags were placed into 1.5-m long core boxes, labeled, and prepared for chemical sampling and lithologic logging.

\section{Lithologic Logs of Sediment Cores}

After sediment samples were collected from a core, USGS scientists took digital photographs and developed a lithologic log. Some sediment was placed under a macroscope to aid the description of samples and to measure the grain diameter of small gravel, sand, and silt (fig. 7). The colors of samples were determined while wet. Color and size of sediment were determined using the Geotechnical Gauge manufactured by W.F. McCollough. A gravelometer was used to measure the B-axis of gravel and cobble. Lithologic logs were transcribed to the Arcmap module CrossView to generate digital logs. All logs and photographs of the sediment cores are presented in appendix A. 


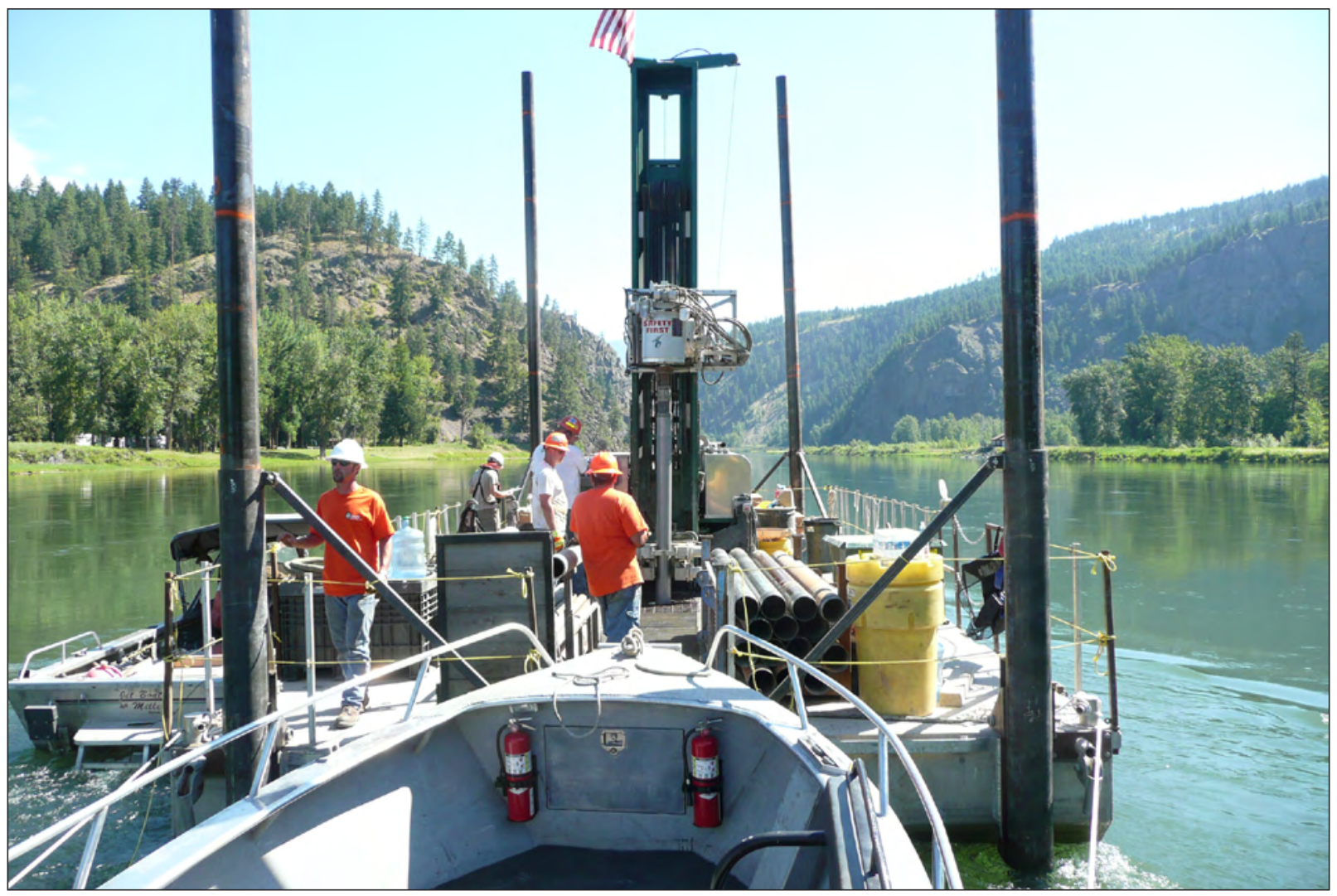

Figure 5. Sediment-coring system on a barge on the Kootenai River, Bonners Ferry, Idaho. (Photograph taken by Gary Barton, U.S. Geological Survey, July 7, 2007.)

\section{Sampling and Chemical Analysis of Sediment Cores}

Free Run Aquatic Research (FRAR) provided procedures for sediment sampling design, protocol, and chemical analysis to KTOI (Gretchen Kruse, Free Run Aquatic Research, written commun., 2007) that were based on Inland Testing Manual (U.S. Environmental Protection Agency, 1998). These procedures subsequently were modified prior to sampling by the USGS to match U.S. Army Corps of Engineers protocols as described in the Northwest Regional Sediment Evaluation Framework manual (U.S. Army Corps of Engineers and others, 2006). The sediment samples from cores were collected and analyzed for select chemicals that are listed in the sediment-quality guidelines: organochlorine pesticides, polynuclear aromatic hydrocarbons (PAHs), polychlorinated biphenyls, (PCBs), metals, total organic carbons (TOC), and asbestos (U.S. Army Corps of Engineers and others, 2006, table 7-1).

Sediment sampling equipment was cleaned at the beginning of each day and before installation at each coring site using the following procedures: (1) wash with deionized water, (2) wash with laboratory-grade detergent, (3) rinse with acetone, and (4) rinse with deionized water. To quickly process and sample the cores and get the sediment samples on ice, the sampling of cores took place on the drilling platform upwind of exhaust fumes and drilling operations. With the core resting in the core box, a clean knife was used to slice open the polyethylene core bag. The interior section of the core was exposed using a clean Teflon spatula to remove the outer layer of sediment in contact with the core barrel because sediment in contact with the inner wall of a core barrel can become contaminated (MacDonald and Ingersoll, 2002). Sampling was limited to silt and sand in the center of the core. Some fine gravel was sampled along with the silt and sand due to the heterogeneity of the sediment. Organochlorine pesticide, $\mathrm{PAH}$, PCB, metal, TOC, and asbestos samples were collected from each sampled depth interval at each core site and analyzed as described in U.S. Army Corps of Engineers and others (2006). Sample depths for chemical analysis are shown on the lithologic logs in appendix A.

Samples for analysis of organochlorine, pesticides, PAHs, PCBs, and TOC analysis were collected as described by the U.S. Army Corps of Engineers and others (2006). A clean stainless steel spatula was used to collect samples of silt and sand from of each sediment core. Samples were placed into a clean, baked glass sample bottle, stored on ice, and processed at the KTOI sample preparation laboratory. Samples for analysis of metals, asbestos, and particle size were collected from the sediment using a clean plastic scoop, placed into clean plastic sample bottles, put on ice, and processed at the KTOI sample preparation laboratory. 


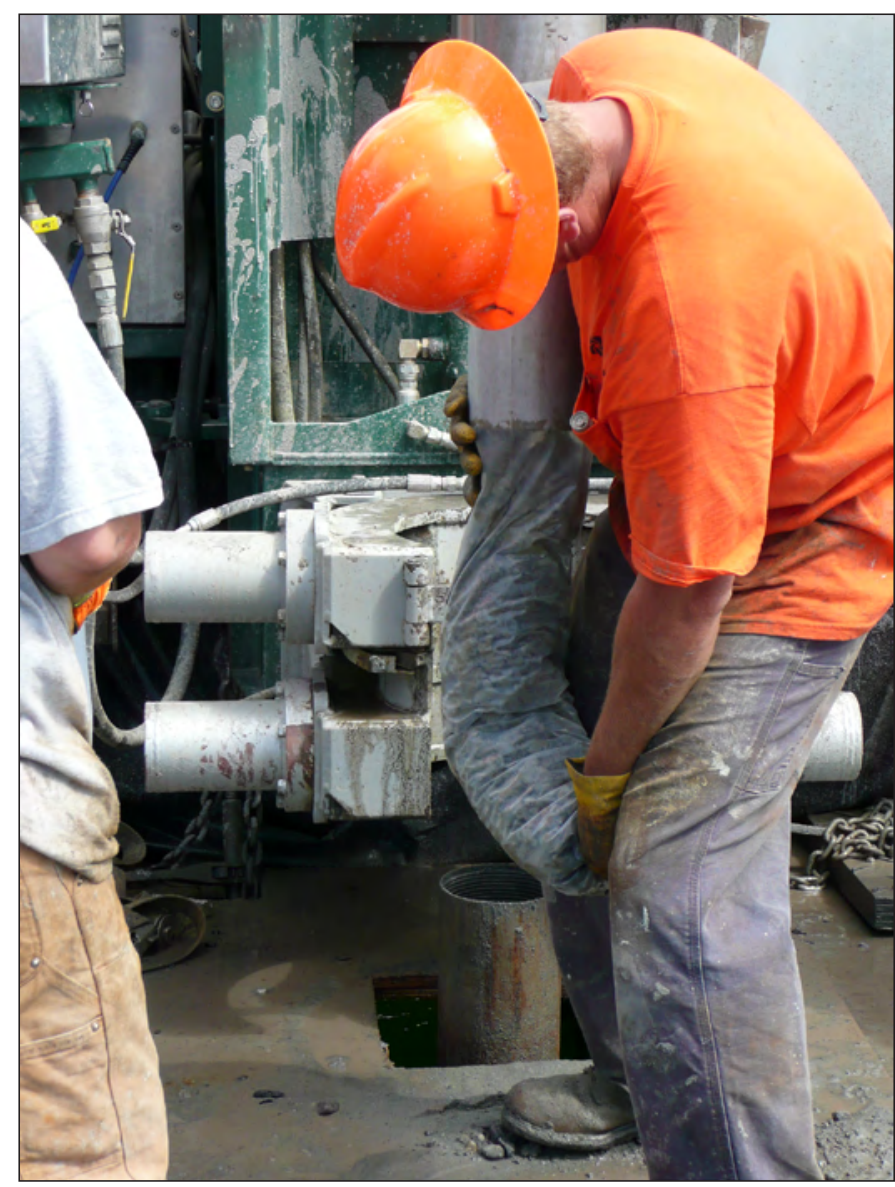

Figure 6. Extrusion of sediments from core barrel into a $1.5-\mathrm{m}$ long polyethylene core bag with a $15.2-\mathrm{cm}$ inside diameter, Kootenai River near Bonners Ferry, Idaho. The sediment core was recovered after the drill pipe and bit was brought up to the drill deck. (Photograph taken by Gary Barton, U.S. Geological Survey, June 2007.)

At the KTOI sample preparation laboratory, the sediment sub-samples from each core were composited into a single homogenized sample for each core site. For each core, an equal volume of sediment from each sampled depth interval was placed in a clean glass-mixing bowl. These sediments were vigorously mixed using a clean, stainless steel mixing spoon. Approximately, $200 \mathrm{~g}$ of homogenized samples were collected for metals analysis, $200 \mathrm{~g}$ for organochlorine pesticide, PCB, and TOC analysis, and $175 \mathrm{~g}$ for asbestos analysis. The composite samples then were placed in plastic and glass sample bottles and stored at about $-10^{\circ} \mathrm{C}$ in a secure building at the KTOI Tribal Hatchery.

After completion of the coring fieldwork, the samples were processed and shipped by FRAR to commercial testing facilities outside the USGS chain of custody for analysis of metals, organochlorine and pesticide compounds, and asbestos. The chemical analyses and results are provided in appendix B.

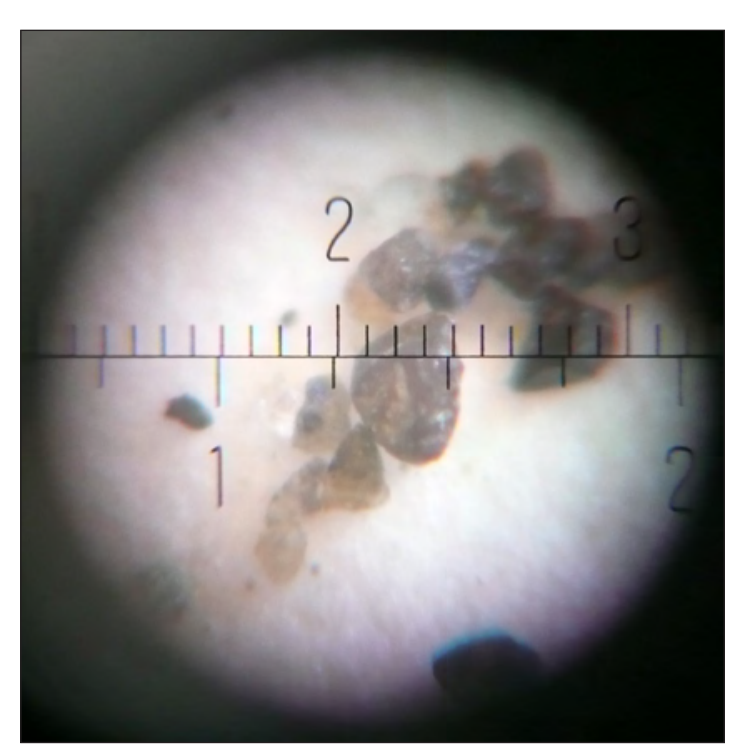

Figure 7. Macroscopic view of sediment sampled from a core collected from the Kootenai River near Bonners Ferry, Idaho. (Photograph taken by Ryan Fosness, U.S. Geological Survey, June 2007.)

Samples for the analysis of PAHs, PCB, and TOC were shipped by overnight courier in sealed coolers using USGS chain-of-custody procedures to the USGS Washington Water Science Center in Tacoma, Washington, for further preparation. The samples were stored in a freezer in a secure laboratory. After processing, these samples were shipped by overnight courier in sealed coolers using USGS chainof-custody procedures to the USGS National Water Quality Laboratory (NWQL) in Lakewood, Colorado.

\section{Chemical Analysis and Sediment Sieving}

Sediment samples were analyzed for PAHs at the NWQL using procedures described by Olson and others (2004) and for PCBs using procedures described by Noriega and others (2004). Sediment samples were analyzed for TOC at the USGS Geologic Division Geochemistry Laboratory, Lakewood, Colorado, following procedures described by Arbogast (1996). The USGS analytical methodology and reporting level for each chemical constituent met or exceeded requirements listed on the sediment-quality guidelines (U.S. Army Corps of Engineers and others, 2006) and analytical results are provided in table 3 . An approximately $25 \mathrm{~g}$ subsample of sediment from each composite sample was dry sieved by the USGS Washington Water Science Center laboratory to measure the percent finer than sand (table 3). The mesh opening of the sieve was $62.5 \mu \mathrm{m}$. Sediment was sieved using procedures described by Guy (1969). 
Table 3. Select polynuclear aromatic hydrocarbons, total polychlorinated biphenyls, and total organic carbon concentrations and sediment-particle sizes in sediment samples collected from cores at the Kootenai River near Bonners Ferry, Idaho, June-July 2007, and sediment-quality guidelines.

[Concentrations in micrograms per kilograms except as noted. Values in bold are non-censored or estimated values between laboratory detection limit and laboratory reporting limit. Sediment quality guideline: Depths below riverbed that sediment subsamples were collected from a core is provided on lithologic logs in appendix A and summarized in table 2. Subsamples were composited into a single sample for a core for chemical analysis. G rain size: Dry sieved at the U.S. Geological Survey, Washington Water Science Center laboratory, Tacoma, Washington. Sediment quality guideline: From U.S. Army Corps of Engineers (2006). Concentrations are in micrograms per kilograms, dry weight, except as noted. Nitrobenzene-d: Laboratory surrogate, bed sediment with particle-size diameter less than 2 millimeters, wet sieved using native water. A bbreviations: PCB, polychlorinated biphenyl; TB, test boring; SRM, standard reference material; E, estimated; m, meter; cm, centimeter; mm, millimeter; NA, not applicable; <, less than; -, no data]

\begin{tabular}{|c|c|c|c|c|c|c|c|c|c|}
\hline Station No. & Date & $\begin{array}{l}\text { Grain size } \\
<0.063 \mathrm{~mm} \\
\text { (percent) }\end{array}$ & $\begin{array}{c}\text { Inorganic } \\
\text { carbon } \\
\text { (percent) }\end{array}$ & $\begin{array}{c}\text { Organic } \\
\text { carbon } \\
\text { (percent) }\end{array}$ & $\begin{array}{c}\text { Total } \\
\text { carbon } \\
\text { (percent) }\end{array}$ & p-Cresol & Naphthalene & $\begin{array}{l}\text { 2-Ethylnaph- } \\
\text { thalene }\end{array}$ & $\begin{array}{l}\text { 2,6-Dimethyl- } \\
\text { naphthalene }\end{array}$ \\
\hline \multicolumn{2}{|c|}{ Sediment quality guideline } & - & - & - & - & - & 500 & - & - \\
\hline \multicolumn{2}{|c|}{ Database parameter No. } & & & & & P49451 & P49402 & P49948 & P49406 \\
\hline TB-1 & $06-20-07$ & 8.6 & - & - & - & - & - & - & - \\
\hline TB-2 & 06-20-07 & 3.5 & - & - & - & - & - & - & - \\
\hline TB-3 & $06-22-07$ & 5.4 & 1.16 & 0.26 & 1.42 & $<100$ & $<100$ & $<100$ & E4 \\
\hline TB-3-2 ${ }^{1}$ & 07-12-07 & 4.8 & 1.3 & $<.05$ & 1.34 & E 9 & E 8 & $<100$ & E 15 \\
\hline TB-4 & $06-21-07$ & 3.4 & - & - & - & - & - & - & - \\
\hline TB-5 & $06-22-07$ & 3.6 & .44 & $<.05$ & .47 & $<100$ & $<100$ & $<100$ & $<100$ \\
\hline TB-7 & $06-27-07$ & 7.5 & .68 & .09 & .77 & $<100$ & $<100$ & $<100$ & $<100$ \\
\hline TB- $7^{1}$ & $06-27-07$ & - & - & - & - & $<100$ & $<100$ & $<100$ & E 16 \\
\hline TB-8 & $06-26-07$ & 4.5 & .54 & .15 & .69 & $<100$ & $<100$ & $<100$ & $<100$ \\
\hline TB-8 ${ }^{1}$ & 06-26-07 & - & .74 & .16 & .90 & $<100$ & $<100$ & $<100$ & $<100$ \\
\hline TB-9 & $06-26-07$ & 10.8 & 1.81 & .61 & 2.42 & 200 & 68 & $<100$ & 110 \\
\hline TB-9 1 & 06-26-07 & - & - & - & - & $<100$ & $<100$ & $<100$ & $<100$ \\
\hline TB-11 & $06-27-07$ & 3.0 & .67 & .08 & .75 & E 20 & E 2 & $<100$ & E 10 \\
\hline TB-12 & 07-11-07 & 84.9 & 1.81 & .56 & 2.37 & $<100$ & $<100$ & $<100$ & E 13 \\
\hline TB- $12^{1}$ & $07-11-07$ & 5.2 & 1.79 & .61 & 2.40 & - & - & - & - \\
\hline TB-13 & 07-11-07 & - & 1.7 & .05 & 1.75 & $<100$ & $<100$ & $<100$ & $<100$ \\
\hline TB-15 & $07-10-07$ & 6.3 & .66 & .05 & .71 & $<100$ & $<100$ & $<100$ & $<100$ \\
\hline TB-16 & $07-10-07$ & 7.0 & .24 & .07 & .31 & $<100$ & $<100$ & $<100$ & $<100$ \\
\hline TB-17 & 07-08-07 & 10.3 & .87 & .15 & 1.02 & $<100$ & $<100$ & $<100$ & $<100$ \\
\hline TB-20 & 07-07-07 & 5.6 & .48 & .05 & .53 & $<100$ & $<100$ & $<100$ & $<100$ \\
\hline TB-21 & $06-24-07$ & 5.5 & 1.91 & .17 & 2.08 & $<100$ & $<100$ & $<100$ & E 4 \\
\hline TB-22 & 06-24-07 & 5.5 & 1.86 & .19 & 2.05 & $<100$ & $<100$ & $<100$ & $<100$ \\
\hline TB-22 ${ }^{1}$ & 06-24-07 & 6.4 & - & - & - & - & - & - & - \\
\hline TB-23 & 06-28-07 & 7.5 & 1.49 & .37 & 1.86 & E 12 & E 19 & $<100$ & E 19 \\
\hline TB-23ำ & $06-28-07$ & - & 1.54 & .41 & 1.95 & E 6 & $<100$ & $<100$ & E 8 \\
\hline TB-24 & $06-21-07$ & 16.8 & - & - & - & - & - & - & - \\
\hline HS-1² Expected & & & - & - & - & - & - & - & - \\
\hline H-1 ${ }^{2}$ Laboratory & ed value & - & - & - & - & E8.4 & E7.6 & $<100$ & $<100$ \\
\hline HS-6 ${ }^{2}$ Expected & & & - & - & - & - & 4,100 & - & - \\
\hline H-6² Laboratory & ed value & - & - & - & - & 178 & 2,420 & 307 & 801 \\
\hline HS- $6^{2}$ Percent re & & & - & - & - & - & 59 & - & - \\
\hline
\end{tabular}


Table 3. Select polynuclear aromatic hydrocarbons, total polychlorinated biphenyls, and total organic carbon concentrations and sediment-particle sizes in sediment samples collected from cores at the Kootenai River near Bonners Ferry, Idaho, June-July 2007, and sediment-quality guidelines. - Continued

[Concentrations in micrograms per kilograms except as noted. Values in bold are non-censored or estimated values between laboratory detection limit and laboratory reporting limit. Sediment quality guideline: Depths below riverbed that sediment subsamples were collected from a core is provided on lithologic logs in appendix A and summarized in table 2. Subsamples were composited into a single sample for a core for chemical analysis. G rain size: Dry sieved at the U.S. Geological Survey, Washington Water Science Center laboratory, Tacoma, Washington. Sediment quality guideline: From U.S. Army Corps of Engineers (2006). Concentrations are in micrograms per kilograms, dry weight, except as noted. Nitrobenzene-d: Laboratory surrogate, bed sediment with particle-size diameter less than 2 millimeters, wet sieved using native water. A bbreviations: TB, test boring; SRM, standard reference material; E, estimated; m, meter; cm, centimeter; mm, millimeter; NA, not applicable; <, less than; -, no data]

\begin{tabular}{|c|c|c|c|c|c|c|c|c|c|}
\hline Station No. & Date & $\begin{array}{l}\text { 1,6-Dimethyl- } \\
\text { naphthalene }\end{array}$ & $\begin{array}{c}\text { Acenaph- } \\
\text { thylene }\end{array}$ & $\begin{array}{l}\text { 1,2-Dimethyl- } \\
\text { naphthalene }\end{array}$ & $\begin{array}{c}\text { Acenaph- } \\
\text { thene }\end{array}$ & $\begin{array}{l}\text { 2,3,6-Trimethyl- } \\
\text { naphthalene }\end{array}$ & $\begin{array}{l}\text { - 1-Methyl- } \\
\text { 9H-fluorene }\end{array}$ & $\begin{array}{l}\text { 2-Methylan- } \\
\text { thracene }\end{array}$ & $\begin{array}{l}\text { 1-Methylphen- } \\
\text { anthrene }\end{array}$ \\
\hline \multicolumn{2}{|c|}{ Sediment quality guideline } & - & 470 & - & 1,100 & - & - & - & - \\
\hline \multicolumn{2}{|c|}{ Database parameter No. } & P49404 & P49428 & P49403 & P49429 & P49405 & P49398 & P49435 & P49410 \\
\hline TB-1 & 06-20-07 & - & - & - & - & - & - & - & - \\
\hline TB-2 & 06-20-07 & - & - & - & - & - & - & - & - \\
\hline TB-3 & $06-22-07$ & $<100$ & $<100$ & $<100$ & $<100$ & $<100$ & $<100$ & $<100$ & E 7 \\
\hline TB-3-2 ${ }^{1}$ & $07-12-07$ & E 16 & $<100$ & $<100$ & $<100$ & $<100$ & $<100$ & $<100$ & E 15 \\
\hline TB-4 & 06-21-07 & - & - & - & - & - & - & - & - \\
\hline TB-5 & 06-22-07 & $<100$ & $<100$ & $<100$ & $<100$ & $<100$ & $<100$ & $<100$ & $<100$ \\
\hline TB-7 & $06-27-07$ & $<100$ & $<100$ & $<100$ & $<100$ & $<100$ & $<100$ & $<100$ & E 20 \\
\hline TB-7 ${ }^{1}$ & 06-27-07 & $<100$ & $<100$ & $<100$ & $<100$ & E 14 & $<100$ & $<100$ & $<100$ \\
\hline TB-8 & $06-26-07$ & $<100$ & $<100$ & $<100$ & $<100$ & $<100$ & $<100$ & $<100$ & $<100$ \\
\hline TB-8 ${ }^{1}$ & 06-26-07 & $<100$ & $<100$ & $<100$ & $<100$ & $<100$ & $<100$ & $<100$ & $<100$ \\
\hline TB-9 & 06-26-07 & 92 & $<100$ & $<100$ & E 27 & E 51 & E 45 & E 50 & 90 \\
\hline TB-91 & 06-26-07 & $<100$ & $<100$ & $<100$ & $<100$ & $<100$ & $<100$ & $<100$ & $<100$ \\
\hline TB-11 & $06-27-07$ & E 10 & $<100$ & $<100$ & $<100$ & $<100$ & $<100$ & $<100$ & E 10 \\
\hline TB-12 & 07-11-07 & E 10 & $<100$ & $<100$ & $<100$ & $<100$ & $<100$ & $<100$ & E 15 \\
\hline TB- $12^{1}$ & 07-11-07 & - & - & - & - & - & - & - & - \\
\hline TB-13 & 07-11-07 & $<100$ & $<100$ & $<100$ & $<100$ & $<100$ & $<100$ & $<100$ & $<100$ \\
\hline TB-15 & 07-10-07 & $<100$ & $<100$ & $<100$ & $<100$ & $<100$ & $<100$ & $<100$ & $<100$ \\
\hline TB-16 & 07-10-07 & $<100$ & $<100$ & $<100$ & $<100$ & $<100$ & $<100$ & $<100$ & $<100$ \\
\hline TB-17 & 07-08-07 & $<100$ & $<100$ & $<100$ & $<100$ & $<100$ & $<100$ & $<100$ & $<100$ \\
\hline TB-20 & 07-07-07 & $<100$ & $<100$ & $<100$ & $<100$ & $<100$ & $<100$ & $<100$ & $<100$ \\
\hline TB-21 & 06-24-07 & E 5 & $<100$ & $<100$ & $<100$ & $<100$ & $<100$ & $<100$ & E 7 \\
\hline TB-22 & 06-24-07 & $<100$ & $<100$ & $<100$ & $<100$ & $<100$ & $<100$ & $<100$ & $<100$ \\
\hline TB-22 ${ }^{1}$ & 06-24-07 & - & - & - & - & - & - & - & - \\
\hline TB-23 & $06-28-07$ & E 19 & $<100$ & $<100$ & $<100$ & E 13 & $<100$ & $<100$ & E 18 \\
\hline TB-23 ${ }^{1}$ & 06-28-07 & E 8 & $<100$ & $<100$ & $<100$ & $<100$ & $<100$ & $<100$ & E9 \\
\hline TB-24 & 06-21-07 & - & - & - & - & - & - & - & - \\
\hline HS- $1^{2}$ Expected & & - & - & - & - & - & - & - & - \\
\hline $\mathrm{H}-1^{2}$ Laboratory & ted value & $<100$ & $<100$ & $<100$ & E11.50 & $<100$ & $<100$ & $<100$ & E23.20 \\
\hline HS-6 ${ }^{2}$ Expected & & - & 190 & - & 230 & - & - & - & - \\
\hline H-6² Laboratory & ted value & 718 & 285 & 236 & 100 & 378 & 154 & 228 & 479 \\
\hline HS- $6^{2}$ Percent re & & - & 150 & - & 43 & - & - & - & - \\
\hline
\end{tabular}


Table 3. Select polynuclear aromatic hydrocarbons, total polychlorinated biphenyls, and total organic carbon concentrations and sediment-particle sizes in sediment samples collected from cores at the Kootenai River near Bonners Ferry, Idaho, June-July 2007, and sediment-quality guidelines.-Continued

[Concentrations in micrograms per kilograms except as noted. Values in bold are non-censored or estimated values between laboratory detection limit and laboratory reporting limit. Sediment quality guideline: Depths below riverbed that sediment subsamples were collected from a core is provided on lithologic logs in appendix A and summarized in table 2. Subsamples were composited into a single sample for a core for chemical analysis. $\mathbf{G}$ rain size: Dry sieved at the U.S. Geological Survey, Washington Water Science Center laboratory, Tacoma, Washington. Sediment quality guideline: From U.S. Army Corps of Engineers (2006). Concentrations are in micrograms per kilograms, dry weight, except as noted. Nitrobenzene-d: Laboratory surrogate, bed sediment with particle-size diameter less than 2 millimeters, wet sieved using native water. Abbreviations: TB, test boring; SRM, standard reference material; E, estimated; m, meter; cm, centimeter; mm, millimeter; NA, not applicable; <, less than; -, no data]

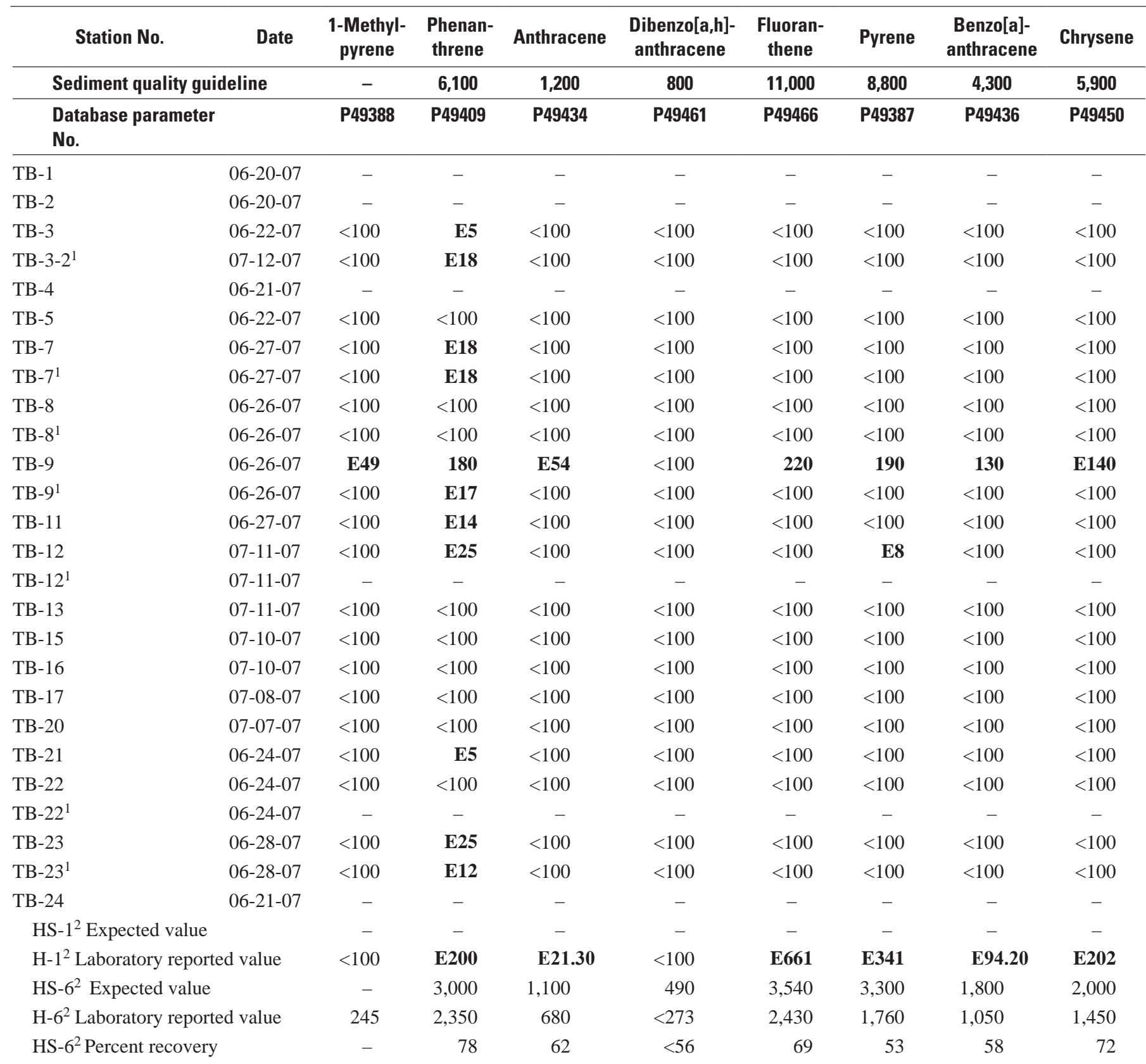


Table 3. Select polynuclear aromatic hydrocarbons, total polychlorinated biphenyls, and total organic carbon concentrations and sediment-particle sizes in sediment samples collected from cores at the Kootenai River near Bonners Ferry, Idaho, June-July 2007, and sediment-quality guidelines. - Continued

[Concentrations in micrograms per kilograms except as noted. Values in bold are non-censored or estimated values between laboratory detection limit and laboratory reporting limit. Sediment quality guideline: Depths below riverbed that sediment subsamples were collected from a core is provided on lithologic logs in appendix A and summarized in table 2. Subsamples were composited into a single sample for a core for chemical analysis. G rain size: Dry sieved at the U.S. Geological Survey, Washington Water Science Center laboratory, Tacoma, Washington. Sediment quality guideline: From U.S. Army Corps of Engineers (2006). Concentrations are in micrograms per kilograms, dry weight, except as noted. Nitrobenzene-d: Laboratory surrogate, bed sediment with particle-size diameter less than 2 millimeters, wet sieved using native water. A bbreviations: TB, test boring; SRM, standard reference material; E, estimated; m, meter; cm, centimeter; mm, millimeter; NA, not applicable; <, less than; -, no data]

\begin{tabular}{|c|c|c|c|c|c|c|c|c|c|}
\hline Station No. & Date & $\begin{array}{c}\text { Benzo[b]- } \\
\text { fluoranthene }\end{array}$ & $\begin{array}{c}\text { Benzo[k]- } \\
\text { fluoranthene }\end{array}$ & $\begin{array}{l}\text { Benzo[a]- } \\
\text { pyrene }\end{array}$ & $\begin{array}{c}\text { Indeno } \\
{[1,2,3-c d]} \\
\text { pyrene }\end{array}$ & $\begin{array}{c}\text { Benzo[ghi] } \\
\text { perylene }\end{array}$ & $\begin{array}{c}\text { 4H-Cyclopenta[def]- } \\
\text { phenanthrene }\end{array}$ & $\begin{array}{c}\text { 9H- } \\
\text { Fluorene }\end{array}$ & Isophorone \\
\hline \multicolumn{2}{|c|}{ Sediment quality guideline } & 600 & 600 & 3,300 & 4,100 & 4,000 & - & 1,000 & - \\
\hline \multicolumn{2}{|c|}{ Database parameter No. } & P49458 & P49397 & P49389 & P49390 & P49408 & P49411 & P49399 & P49400 \\
\hline TB-1 & 06-20-07 & - & - & - & - & - & - & - & - \\
\hline TB-2 & 06-20-07 & - & - & - & - & - & - & - & - \\
\hline TB-3 & $06-22-07$ & $<100$ & $<100$ & $<100$ & $<100$ & $<100$ & $<100$ & $<100$ & $<100$ \\
\hline TB-3- $2^{1}$ & $07-12-07$ & $<100$ & $<100$ & $<100$ & $<100$ & $<100$ & $<100$ & $<100$ & $<100$ \\
\hline TB-4 & 06-21-07 & - & - & - & - & - & - & - & - \\
\hline TB-5 & $06-22-07$ & $<100$ & $<100$ & $<100$ & $<100$ & $<100$ & $<100$ & $<100$ & $<100$ \\
\hline TB-7 & 06-27-07 & $<100$ & $<100$ & $<100$ & $<100$ & $<100$ & $<100$ & $<100$ & $<100$ \\
\hline TB-7 ${ }^{1}$ & 06-27-07 & $<100$ & $<100$ & $<100$ & $<100$ & $<100$ & $<100$ & $<100$ & $<100$ \\
\hline TB-8 & 06-26-07 & $<100$ & $<100$ & $<100$ & $<100$ & $<100$ & $<100$ & $<100$ & $<100$ \\
\hline TB-8 ${ }^{1}$ & 06-26-07 & $<100$ & $<100$ & $<100$ & $<100$ & $<100$ & $<100$ & $<100$ & $<100$ \\
\hline ТВ-9 & 06-26-07 & 160 & E 63 & 100 & $<63$ & E 65 & E 38 & E 27 & $<100$ \\
\hline TB-91 & $06-26-07$ & $<100$ & $<100$ & $<100$ & $<100$ & $<100$ & $<100$ & $<100$ & $<100$ \\
\hline TB-11 & 06-27-07 & $<100$ & $<100$ & $<100$ & $<100$ & $<100$ & $<100$ & $<100$ & $<100$ \\
\hline TB-12 & 07-11-07 & $<100$ & $<100$ & $<100$ & $<100$ & E 9 & $<100$ & $<100$ & $<100$ \\
\hline TB-12 1 & 07-11-07 & - & - & - & - & - & - & - & - \\
\hline TB-13 & 07-11-07 & $<100$ & $<100$ & $<100$ & $<100$ & $<100$ & $<100$ & $<100$ & $<100$ \\
\hline TB-15 & 07-10-07 & $<100$ & $<100$ & $<100$ & $<100$ & $<100$ & $<100$ & $<100$ & $<100$ \\
\hline TB-16 & 07-10-07 & $<100$ & $<100$ & $<100$ & $<100$ & $<100$ & $<100$ & $<100$ & $<100$ \\
\hline TB-17 & 07-08-07 & $<100$ & $<100$ & $<100$ & $<100$ & $<100$ & $<100$ & $<100$ & $<100$ \\
\hline TB-20 & 07-07-07 & $<100$ & $<100$ & $<100$ & $<100$ & $<100$ & $<100$ & $<100$ & $<100$ \\
\hline TB-21 & $06-24-07$ & $<100$ & $<100$ & $<100$ & $<100$ & $<100$ & $<100$ & $<100$ & $<100$ \\
\hline TB-22 & $06-24-07$ & $<100$ & $<100$ & $<100$ & $<100$ & $<100$ & $<100$ & $<100$ & $<100$ \\
\hline TB-22 ${ }^{1}$ & 06-24-07 & - & - & - & - & - & $<100$ & - & - \\
\hline TB-23 & 06-28-07 & $<100$ & $<100$ & $<100$ & $<100$ & $<100$ & $<100$ & $<100$ & $<100$ \\
\hline TB-23 ${ }^{1}$ & 06-28-07 & $<100$ & $<100$ & $<100$ & $<100$ & $<100$ & $<100$ & $<100$ & $<100$ \\
\hline TB-24 & 06-21-07 & - & - & - & - & - & - & - & - \\
\hline HS- $1^{2}$ Expected & & - & - & - & - & - & - & - & - \\
\hline H-12 Laboratory & ed value & E 219 & E88.10 & $\mathbf{E} 65.20$ & E67.9 & E70.10 & E22.5 & $<100$ & E7.8 \\
\hline HS- $6^{2}$ Expected & & 2,800 & 1,430 & 2,200 & 1,950 & 1,780 & - & 470 & - \\
\hline H-6² Laboratory & ed value & 2,310 & 853 & 972 & $<856$ & 910 & 225 & 191 & E26.4 \\
\hline HS- $6^{2}$ Percent rec & & 82 & 60 & 44 & $<44$ & 51 & - & 41 & - \\
\hline
\end{tabular}


Table 3. Select polynuclear aromatic hydrocarbons, total polychlorinated biphenyls, and total organic carbon concentrations and sediment-particle sizes in sediment samples collected from cores at the Kootenai River near Bonners Ferry, Idaho, June-July 2007, and sediment-quality guidelines.-Continued

[Concentrations in micrograms per kilograms except as noted. Values in bold are non-censored or estimated values between laboratory detection limit and laboratory reporting limit. Sediment quality guideline: Depths below riverbed that sediment subsamples were collected from a core is provided on lithologic logs in appendix A and summarized in table 2. Subsamples were composited into a single sample for a core for chemical analysis. G rain size: Dry sieved at the U.S. Geological Survey, Washington Water Science Center laboratory, Tacoma, Washington. Sediment quality guideline: From U.S. Army Corps of Engineers (2006). Concentrations are in micrograms per kilograms, dry weight, except as noted. Nitrobenzene-d: Laboratory surrogate, bed sediment with particle-size diameter less than 2 millimeters, wet sieved using native water. A bbreviations: TB, test boring; SRM, standard reference material; E, estimated; m, meter; cm, centimeter; mm, millimeter; NA, not applicable; <, less than; -, no data]

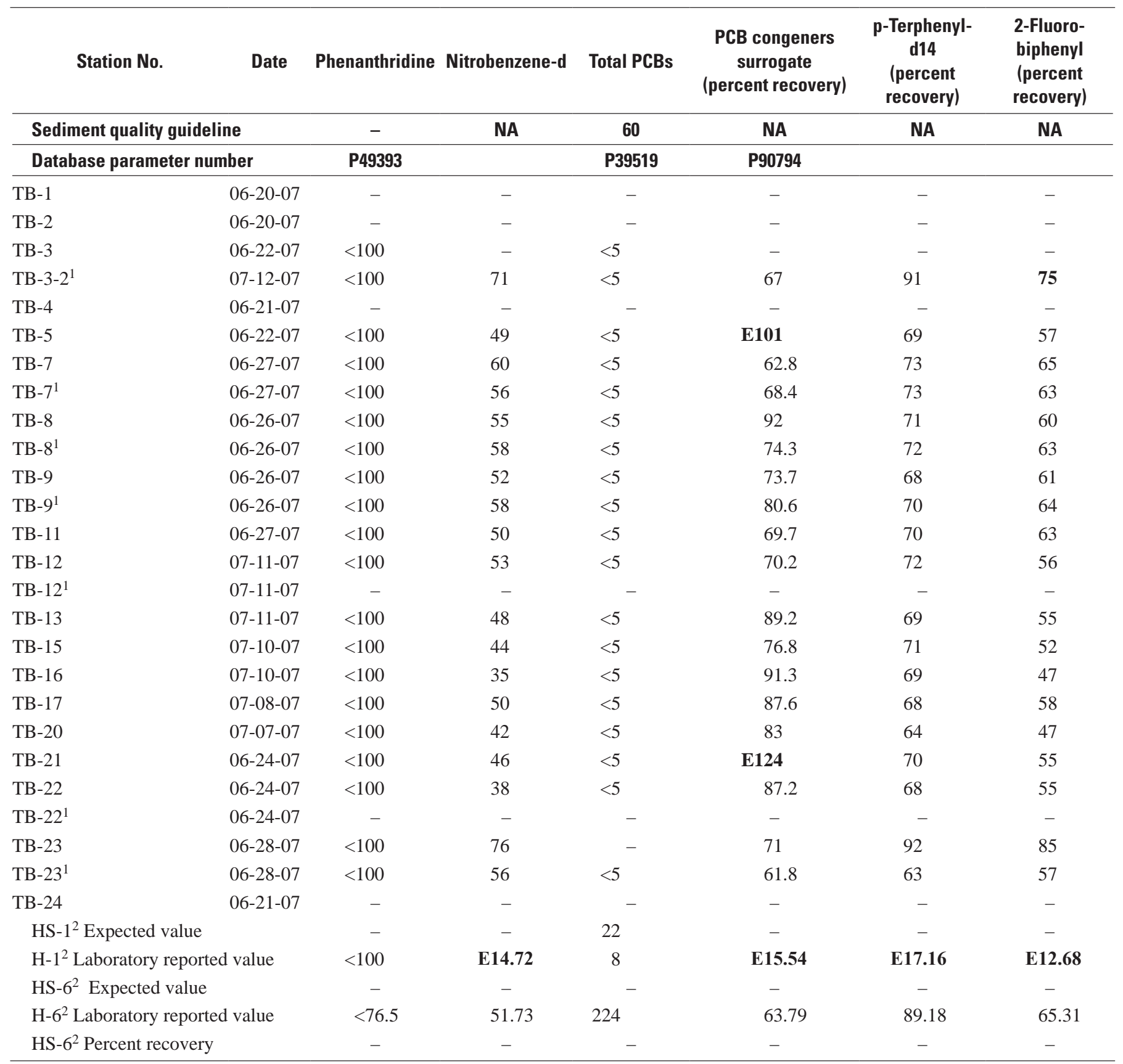

${ }^{1}$ Duplicate quality-assurance sample.

${ }^{2}$ Standard reference material quality-assurance sample from National Research Council of Canada (http://www.nrc-cnrc.gc.ca/eng/programs/imb/crmp.html). 


\section{Data Archives}

USGS chemical data presented in this report are stored in the USGS National Water Information System (NWIS). NWIS is a comprehensive and distributed application that supports the acquisition, processing, and long-term storage of water data including sediment chemical data. The chemical data are publicly available on the NWISWeb at http://waterdata.usgs. gov/nwis/qw.

\section{Quality Assurance}

Quality assurance and control were incorporated into field and laboratory procedures to assure that data generated were of known and acceptable quality. Quality-assurance procedures included collection of samples using noncontaminating protocols, laboratory analysis of the samples following rigorously proven laboratory procedures, and insertion of quality-control samples in the sample set to assess the effectiveness of these procedures.

Bias and variability in the sample data were assessed using blank samples to detect bias originating in either the field or the laboratory. Duplicate samples were used to assess variability in field sampling or laboratory analysis. Accuracy in the analytical process was assessed by using certified standard reference materials inserted as blind samples from the field and the addition of surrogate compounds added to the samples being analyzed.

Quality-control samples were generated in the field and in the laboratory. Laboratory quality-control samples included analysis of reagent blank samples to assess bias in the analytical process. The NWQL protocol is to analyze one duplicate, one analytical blank, and one spiked sample with each set of 12 environmental samples (Noriega and others 2004). The NWQL analyzed several surrogate compounds with each regular and replicate sediment sample. Surrogate compounds are readily identifiable non-target compounds, which are added to the sample in known quantities so that recovery of sample extraction process can be assessed. Known quantities of surrogate compounds were added to the sediment samples being analyzed for organic compounds. Recovery of the surrogate compounds is a good indicator of how well the organic extraction process detected organic compounds in the sediment samples. Laboratory duplicate samples provided data on variability in the ensuing data arising from variability in the laboratory process.

Accuracy in the analysis of organic chemical data was assessed by use of standard reference materials. Standard reference materials, HS-1 and HS-6, which list known concentrations of selected PAHs and PCBs, were obtained from the National Research Council Canada. These standard reference materials were submitted to the NWQL as blind samples with the other samples (table 3) and document bias and recovery of the analytical process.
Duplicate field samples were collected at five cores sites. The duplicate samples were collected following the composite sample mixing process and assess the degree of homogeneity in the composite sample. The duplicate samples were collected by adding alternating spoon-sized scoops of composited sediment first to one sample bottle and then to another.

Twenty equipment rinsate blank samples were collected after decontamination of the core barrel and prior to sampling. Decontamination of the core barrel consisted of pressure spraying deionized water into the barrel and collecting the run-off in a plastic jar as it flowed out the end of barrel. Equipment blanks also were collected from the clean sample jar prior to compositing the samples. Six of these equipment blanks were analyzed for metals.

Trip blanks were collected to document any contamination attributable to field handling, procedures, and shipping. The blank was created by exposing analyte-free water to the atmosphere during sample processing and then analyzing for metals. These blanks were used by Kruse (2008) to document any contamination attributable to field handling procedures and shipping.

\section{Sediment Chemistry of Cores From the Kootenai River}

Habitat-ecosystem restoration projects for the Kootenai River may require moving and dredging the riverbed, and these actions may cause sediment to spread along the river with any contaminant(s) possibly bound to the sediment. Kruse (2000) reported multiple sources of historical contaminant input to the Kootenai River. Many sources of contaminants have been reduced or eliminated during the past 30 years. Recent monitoring efforts, however, have detected the presence of organochlorine pesticides, PCBs, and metals in the Kootenai River ecosystem in the Idaho and British Columbia reaches (Knudson, 1994; Kruse and Scarnecchia, 2002; Kruse, 2003; and Kruse, 2005). The USGS analyzed the sediment chemistry for 16 of 24 cores from the Kootenai River. The sediment in four cores was too coarse for chemical analysis. This study determined that concentrations of 29 PAHs and total PCBs in composite sediment samples from 16 cores were substantially less than concentrations considered to be contaminated as recognized in the Pacific Northwest regional sediment evaluation framework (U.S. Army Corps of Engineers and others, 2006). Reported concentrations for all selected PAHs and total PCBs analyzed for in the sediments samples were less than $220 \mu \mathrm{g} / \mathrm{kg}$. Concentrations of sediment chemistry and guidelines for sediment-quality are shown in table 3. 
Quality-control data indicate that the collected data met the quality objectives of the study, although chemical concentrations reported by the NWQL were affected by a negative bias. Two blind standard reference material samples were submitted with the sample set to NWQL to assess bias in the analytical procedures. The standard reference material (SRM) used in samples HS-1 (total PCBs) and HS-6 (PAHs) were obtained from National Research Council of Canada (2010). All analytes certified as present in the SRM samples were detected by the NWQL analytical procedures; however, the recoveries tended to be lower than the most probable expected values (table 3). The median of comparisons between laboratory-reported values and most probable expected values present in the SRM was 59 percent, with a range of 41 to 150 percent.

Spike matrix recoveries for analytes added to each sample analyzed ranged from 63 and 77 percent and were within laboratory control limits. Positive bias in the analytical data was not apparent in the data as no target analytes were observed in the laboratory blank samples analyzed by NWQL or in the field rinsate blank samples analyzed with samples (appendix B). These results indicate that although laboratory results have a negative bias, they are not likely to result in a false negative indication of absence of contaminant in the sediment samples.

Based on low recoveries of the SRM and spike samples, the minimum reporting level shown in table 3 as a less than value was increased by a factor of 2 over the minimum reporting level provided with the laboratory analysis. A less than $50 \mu \mathrm{g} / \mathrm{kg}$ reported by the laboratory is re-censure as less than $100 \mu \mathrm{g} / \mathrm{kg}$ in table 3 . The laboratory provided an estimated concentration value when the instrument indicted that the specific analyte was present but at a concentration less than the range of the lowest calibration standard. The estimated values are presented in table 3 as provided by the laboratory and have not been adjusted.

The reported concentrations of total PCBs in sediment samples from all 16 cores were less than $5 \mu \mathrm{g} / \mathrm{kg}$; concentrations of PCBs were not carbon normalized. The sediment-quality guideline for concentrations of total PCBs in dredged sediments is $60 \mu \mathrm{g} / \mathrm{kg}$.

The concentration of PAHs measured in the composite sediments for Kootenai River was substantially less than the sediment-quality guideline for dredged sediments. Reported concentrations for the $29 \mathrm{PAH}$ compounds analyzed typically were less than the laboratory reporting level, as shown in table 3 . Fewer than five PAH compounds were detected and concentrations typically were less than $220 \mu \mathrm{g} / \mathrm{kg}$ for 64 percent of the composite samples. Sample TB-9, however, indicated the presence of 23 PAHs compounds, although only phenanthrene was detected in the duplicated sample from that composite. The comparatively large PAH concentrations in the sample from TB-9 may have resulted from charred organic fragments similar to the large charred woody debris that was observed on the $2 \mathrm{~mm}$ screen used in sample preparation for organic carbon analysis. Less variability between duplicates was observed in the other four duplicate sample pairs, TB-3, TB-7, TB-8, and TB-12, indicating that constituent concentrations are consistently low, but that the variability in constituent concentration can be relatively large, as often is the case when measuring low concentrations of environmental constituents.

Concentrations of TOC ranged from 0.31 to 2.42 percent (table 3). Grain sizes finer than sand for the 18 sieved samples ranged from 3.0 percent in TB-11 to 84.9 percent in TB-12, with a median of 5.6 percent fines. A layer of clay and silt was sampled from TB-12. Because the concentration of PAHs and PCBs were low, the toxic equivalencies, probable effects quotients, and theoretical bioaccumulation potential are not reported.

\section{Summary}

River restoration is a complex undertaking that requires a thorough understanding of the river and flood plain landscape. Evaluating the feasibility of proposed white sturgeon habitatecosystem restoration projects, such as modifying the channel and flood plain and installing in-stream structures requires many types of information that includes analyzing chemicals in sediment beneath the riverbed and a detailed understanding of sediment types beneath the river and in the nearby flood plain, river stage, and groundwater levels.

The U.S. Geological Survey collected and analyzed critical data for the Kootenai River habitat restoration project. Sediment cores were collected at 23 locations during July 2007 in the Kootenai River white sturgeon habitat. Sediment coring site selection was based on a preliminary conceptual river design and the potential effect of bedrock on rechannelizing the river. A sonic drill rig was mounted on a drilling barge and collected continuous cores of sediments beneath the riverbed. Core depths ranged from 4.6 to 15.2 meters and 21 cores reached a depth of 15.2 meters. A maximum coring depth of 15.2 meters below the riverbed was established for the coring program because the channel modifications under consideration are not likely to extend to depths much greater than 15.2 meters. Lithologic logs were constructed and photographs were taken of the cores. Sediment samples were collected from these cores and analyzed by the U.S. Geological Survey for polyaromatic hydrocarbons, polychlorinated biphenyls, total organic carbon, and sieved for particle size. 
Habitat-ecosystem restoration projects for the Kootenai River may require moving and dredging the riverbed. These actions may cause sediment to spread along the river with any contaminant(s) possibly bound to the sediment. This study determined that concentrations of PAHs and total PCBs in the sediment sampled in all cores were less than the sediment quality guidelines for river sediment dredging. Total organic carbon concentrations ranged from 0.31 to 2.42 percent. For the 19 sieved samples collected, the median percent finer than sand was 5.6 percent with a minimum of 3.0 percent and maximum of 84.9 percent fines. Because the concentration of PAHs and PCB are low, the toxic equivalencies, probable effects quotients, and theoretical bioaccumulation potential are not reported.

\section{Acknowledgments}

The authors thank the people of the Kootenai River Valley in Idaho who provided access to the Kootenai River for coring. Sue Ireland of the Kootenai Tribe of Idaho provided storage facilities for USGS boats and equipment and a sample preparation lab. Gretchen Kruse of Free Run Aquatics provided sampling equipment. The authors also thank Jack Siple of the Kootenai Tribe of Idaho who provided logistical support for fieldwork. Andre Makarov, USGS Washington Water Science Center, collected data on the Kootenai River for this project. Regan Huffman, USGS Washington Science Center, helped enter the analytical data into the USGS database and generated chemical data tables. Sandra Ball, USGS, Post Falls, Idaho, helped with many logistical issues.

\section{References Cited}

Allen, J.E., and Burns, Marjorie, 1986, Cataclysms on the Columbia: Portland, Oreg., Timber Press, Inc., 213 p.

Arbogast, B.F., 1996, Analytical methods manual for the Mineral Resource Surveys Program: U.S. Geological Survey Open-File Report 96-525, 248 p.

Atwater, F.A., 1986, Pleistocene glacial-lake deposits of the Sanpiol River valley, northeastern Washington: U.S. Geological Survey Bulletin 1661, 39 p.

Barton, G.J., 2004, Characterization of channel substrate, and changes in suspended-sediment transport and channel geometry in white sturgeon spawning habitat in the Kootenai River near Bonners Ferry, Idaho, following the closure of Libby Dam: U.S. Geological Survey WaterResources Investigations Report 03-4324, 33 p. (Also available at http://id.water.usgs.gov/PDF/wri034324/ new034324-5 19.pdf.)
Barton, G.J., McDonald, R.R., and Nelson, J.M., 2009, Simulation of flow using a multidimensional flow model for white sturgeon habitat, Kootenai River near Bonners Ferry, Idaho (supplement to U.S. Geological Survey Scientific Investigations Report 2005-5230): U.S. Geological Survey Scientific Investigations Report 2009-5026, 34 p.

Barton, Gary, McDonald, Richard, Nelson, Jonathan Berenbrock, Charles, Donato, Mary, VanMetre, Pete, and Mahler, Barbara, 2006, Altered dynamics of the Kootenai River white sturgeon spawning habitat and flow modeling in Proceedings of the Joint $8^{\text {th }}$ Federal Interagency Sedimentation Conference, and the $3^{\text {rd }}$ Federal Interagency Hydrologic Modeling Conference, Reno, Nev., April 2-6, 2006, 8 p., accessed January 30, 2007, at http://pubs.usgs. gov/misc reports/FISC 1947-2006/pdf/1st-7thFISCsCD/8thFISC/8thFISC Barton.pdf.

Barton, G.J., McDonald, R.R., Nelson, J.M., and Dinehart, R.L, 2005, Simulation of flow and sediment mobility using a multidimensional flow model for the white sturgeon critical-habitat reach, Kootenai River near Bonners Ferry, Idaho: U.S. Geological Survey Scientific Investigations Report 2005-5230, 54 p. (Also available at http://pubs.usgs. gov/sir/2005/5230/pdf/sir20055230.pdf.)

Berenbrock, Charles, 2005, Simulation of hydraulic characteristics in the white sturgeon spawning habitat of the Kootenai River near Bonners Ferry, Idaho: U.S. Geological Survey Scientific Investigations Report 2005-5110, 30 p. (Also available at http://pubs.usgs.gov/sir/2005/5110/.)

Berenbrock, Charles, and Bennett, J.P., 2005, Simulation of flow and sediment transport in the white sturgeon spawning habitat of the Kootenai River near Bonners Ferry, Idaho: U.S. Geological Survey Scientific Investigations Report 2005-5173, 72 p. (Also available at http://pubs.usgs.gov/ $\underline{\operatorname{sir} / 2005 / 5173 / .)}$

Buchanan, J.P., 1989, Reconnaissance hydrogeologic study of the Kootenai River valley near Bonners Ferry, Idaho: Upper Columbia United Tribes Fisheries Center Fisheries Technical Report no. 25, variously paged.

Dion, N.P., and Whitehead, R.L., 1973, A ground-water monitor network for Kootenai Flats, Northern Idaho: U.S. Geological Survey, Idaho Department of Water Administration Water Information Bulletin no. 33, 43 p.

Guy, H.P., 1969, Laboratory Theory and Methods for Sediment Analysis: U.S. Geological Survey Techniques of Water-Resources Investigations, book 5, chap. C1, 58 p.

J-U-B Engineers, Inc., 1998, Hatchery improvements for the recovery of white sturgeon: Hydrogeologic investigation: Spokane, Wash., J-U-B Engineers, Inc., variously paged. 
Kahle, S.C., Taylor, W.A., Lin, Sonja, Sumioka, S.S., and Olsen, T.D., 2010, Hydrogeologic framework, groundwater and surface-water systems, land use, pumpage, and water budget of the Chamokane Creek basin, Stevens County, Washington: U.S. Geological Survey Scientific Investigations Report 2010-5165, 60 p., 2 pl.

Knudson, K., 1994, Water quality status report-Kootenay (Kootenai) River basin British Columbia, Montana and Idaho in Report of Ecological Resource Consulting to the Kootenai River Network, Libby, Montana: Helena, Montana, Ecological Resource Consulting, 75 p.

Kock, T.J., Congleton, J.L., and Anders, P.J., 2006, Effects of sediment cover on survival and development of white sturgeon embryos: North American Journal of Fisheries Management 26, v. 1, p. 134-141.

Kruse, G.O., and Scarnecchia, D.L., 2002, Assessment of bioaccumulated metal and organochlorine compounds in relation to physiological biomarkers in Kootenai River white sturgeon: Journal of Applied Ichthyology, v. 18, p. $430-438$.

Kruse, Gretchen, 2000, The effects of contaminants on reproduction, embryo development and related physiological processes in Kootenai River White Sturgeon, Acipenser Transmontanus: Moscow, University of Idaho, Masters thesis, $178 \mathrm{p}$.

Kruse, Gretchen, 2003, 2001 Kootenai River macro invertebrate contaminant study—Report prepared for the Kootenai Tribe of Idaho, Bonners Ferry: Free Run Aquatics, variously paginated.

Kruse, Gretchen, 2005. Shorty’s Island (Kootenai River) sediment core analysis report-PCBs, organochlorine pesticides and metals analysis-Report prepared for the Kootenai Tribe of Idaho, Bonners Ferry: Free Run Aquatics, variously paginated.

Kruse, Gretchen, 2008, Kootenai River sediment drillingcontaminant assessment-Draft report prepared for the Kootenai Tribe of Idaho, Bonners Ferry: Free Run Aquatics, variously paginated.

MacDonald, D.D., and Ingersoll, C.G., 2002, A guidance manual to support the assessment of contaminated sediments in freshwater ecosystems - Volume II, Design and implementation of sediment quality investigations: Chicago, Ill., Great Lakes National Program Office, U.S. Environmental Protection Agency document no. EPA-905B02-001-B, variously paginated.
McDonald, Richard, Barton, Gary, Nelson, Jonathan, and Paragamian, Vaughn, 2006, Modeling hydraulic and sediment transport processes in white sturgeon spawning habitat on the Kootenai River, Idaho: Proceedings of the Joint 8th Federal Interagency Sedimentation and 3rd Federal Interagency Hydrologic Modeling Conference, 8 p., accessed June 24, 2010, at http://pubs.usgs.gov/ misc reports/FISC 1947-2006/pdf/1st-7thFISCsCD/8thFISC/8thFISC McDonald.pdf.

McDonald, R.R., Nelson, J.M., and Bennett, J.P., 2005, Multidimensional surface-water modeling system user's guide, U.S. Geological Survey Techniques and Methods 6-B2, $136 \mathrm{p}$.

Miller, F.K., and Burmester, R.F., 2004, Geologic map of Bonners Ferry 30 minute by 60 minute quadrangle, Idaho and Montana: U.S. Geological Survey Miscellaneous Field Studies Map, MS-2426, 28 p., 1 sheet.

National Research Council of Canada, 2010, Certified reference materials program: National Research Council of Canada website, accessed November 4, 2010, at http:// www.nrc-cnrc.gc.ca/eng/programs/imb/crmp.html.

Newell, T.R., 1933, Effects of proposed regulated water levels, Kootenai River, on water table and drainage outlets, Kootenai Valley Drainage Districts: U.S. Geological Survey, $86 \mathrm{p}$.

Noriega, M.C., Wydoski, D.S., and Foreman, W.T., 2004, Methods of analysis by U.S. Geological Survey National Water Quality Laboratory—Determination of organochlorine pesticides and polychlorinated biphenyls in bottom and suspended sediment by gas chromatography with electron-capture detection: U.S. Geological Survey Water-Resources Investigations Report 03-4293, 46 p.

Olson, M.C., Iverson, J.L., Furlong, E.T., and Schroeder, M.P., 2004, Methods of analysis by U.S. Geological Survey National Water Quality Laboratory-Determination of polycyclic aromatic hydrocarbon compounds in sediment by gas chromatography/mass spectrometry: U.S. Geological Survey Water-Resources Investigations Report 03-4318, $45 \mathrm{p}$.

Paragamian, V. L., Kruse, G., and Wakkinen, V., 1995, Kootenai River white sturgeon investigations: Boise, Idaho Department of Fish and Game, prepare for Bonneville Power Administration, Annual Progress Report, Project 88-65.

Paragamian, V.L., Kruse, G., and Wakkinen, V., 1996, Kootenai River white sturgeon investigations: Boise, Idaho Department of Fish and Game, prepared for Bonneville Power Administration, Annual Progress Report, Project 88-65, $70 \mathrm{p}$. 
Paragamian, V.L., Kruse, G., and Wakkinen, V., 1997, Kootenai River white sturgeon investigations: Boise, Idaho Department of Fish and Game, prepared for Bonneville Power Administration, Annual Progress Report, Project 88-65.

Paragamian, V.L., Kruse, G., and Wakkinen, V., 1998, Kootenai River white sturgeon investigations: Boise, Idaho Department of Fish and Game, prepared for Bonneville Power Administration, Annual Progress Report, Project 88-65.

Paragamian, V.L., Kruse, G., and Wakkinen, V., 1999, Kootenai River white sturgeon investigations: Boise, Idaho Department of Fish and Game, prepared for Bonneville Power Administration, Annual Progress Report, Project 88-65.

Paragamian, V.L., Wakkinen, V.D., and Kruse, G., 2002, Spawning habitat of Kootenai River white sturgeon, postLibby Dam: American Journal of Fisheries Management, v. 21, p. 22-23.

Parsley, M.J., and Beckman, L.G., 1994, White sturgeon spawning and rearing habitat in the lower Columbia River: North American Journal of Fish Management, v. 14, p. 812-827.

River Design Group, Inc., 2009, Kootenai River habitat restoration master plan: Whitefish, Montana, River Design Group, Inc., variously paginated.

Tetra Tech, Inc., 2003, Kootenai River geomorphic assessment: Seattle, Wash., Tetra Tech, Inc., 114 p.
U.S. Army Corps of Engineers, 2005, Kootenai Flats seepage analysis, groundwater modeling report, Upper Columbia alternative flood control and fish operations environmental impact statement: Seattle District, U.S. Army Corps of Engineers, variously paginated.

U.S. Army Corps of Engineers and others, 2006, Northwest regional sediment evaluation framework: U.S. Army Corps of Engineers Interim Final September 2006, variously paginated, accessed September 30, 2010, at http://www. clu-in.org/download/contaminantfocus/sediments/RSET Interim FinalNorthwestRegion.pdf.

U.S. Environmental Protection Agency, 1998, Evaluation of dredged material proposed for discharge in waters of the U.S.-Testing Manual: U.S. Environmental Protection Agency, Inland Testing Manual, EPA-823-B-98-004, variously paginated.

U.S. Fish and Wildlife Service, 2006, Biological opinion on effects to listed species from operation of the Federal Columbia River Power System: Portland, Oreg., U.S. Fish and Wildlife Service, variously paginated.

U.S. Geological Survey, 1966, Thirty years on the Kootenai, 1928-58 - A review of Kootenai investigation files: U.S. Geological Survey, 69 p. 


\section{Appendix A. Lithologic Strip Logs With Sediment Sampling Depth Interval for Chemical Analysis and Photographs of Sediment Cores}

Lithologic strip log and photographs of sediment cores from the Kootenai River, Bonners Ferry, Idaho, are presented in appendix A. Each log includes links to photographs; click on a link to view photographs individually. These logs and photographs are available at http:/pubs.usgs.gov/sir/2011/5006/. 


\section{Appendix B. Sediment Core Chemical Analysis Data}

Free Run Aquatic Research, Hayden, Idaho, processed sediment samples collected by the U.S. Geological Survey (USGS) from cores of the Kootenai River. The samples were analyzed for asbestos, which is associated with the mineral tremolite, metals, organochlorine and pesticide compounds, and polynuclear aromatic hydrocarbons (PCBs). These samples were sent to commercial testing facilities outside the USGS chain of custody. Tremolite analysis was done by EMSL Analytical, Inc., in San Leandro, California. Metals and total organic carbon analyses were done by ALS Laboratory Group, Vancouver, British Columbia, Canada. Organochlorine and PCB analyses were done by Axys Analytical Services, LTD, Sidney, British Columbia, Canada. The chemical analysis from Kruse (2008) is provided in the appendix B and was prepared and presented by Free Run Aquatic Research. These data have not been reviewed or approved by the USGS. 
Kootenai River Sediment Drilling: Contaminant Assessment Report (Report Prepared in Partial Fullfillment of Project Number 200200200: Restore Natural Recruitment of Kootenai River White Sturgeon)

\author{
Report Prepared For: \\ Kootenai Tribe of Idaho \\ Bonners Ferry
}

Report Prepared By:

Gretchen Kruse

Free Run Aquatic Research

214 E. Hayden Ave.

Hayden ID 83835

February 2008 


\section{Laboratory Analvsis}

Tremolite: Tremolite analysis was conducted by EMSL Analytical, Inc. in San Leandro California. Twenty soil samples were milled and prepped following CARB 435 guidelines (EPA2). Target analytical sensitivity was set to $0.1 \%$. Each sample was analyzed by both Polarized Light Microscopy (PLM) and

Transmission Electron Microscopy (TEM). For each sample processed by PLM, samples were initially scanned by stereoscopic exam for properties and possible fibrous material. Following initial scan, samples were analyzed using a combination of $100 \mathrm{X}$ and $400 \mathrm{X}$ magnification, employing a 1,000 Point Count procedure following the EPA 600/R-93-116 method (EPA2). Transmission Electron Microscopy involved analysis using EPA 600/R-93-116, Section 2.5.5.2 method for asbestos percent by mass. Asbestos fibers are defined as having a 3:1 aspect ratio and were categorized based on length: (a) $<5.0$ microns and (b) $\geq 5.0$ microns.

Metals: Analysis for metals was conducted by ALS Laboratory Group, Vancouver B.C., Canada. Sediment samples were analyzed for:

- Hardness

- CSR pH by $1: 2$ water leach

- Percent moisture

- Total mercury by CVAFS (cold vapour Fluorescent Atomic Spectrometry)

- ICPMS (Inductively Coupled Plasma - Mass Spectrometry) for thallium (T1) by CSR SALM (Contaminated Sites Regulation Strong Acid Leachable Metals)

- Metals by ICP-OES (inductively coupled plasma-optical emission spectrometry)

Total Organic Carbon: ALS Laboratory Group analysed Total Organic Carbon (TOC) in sediment samples by high temperature combustion (APHA Method 5310; EPA2).

Organochlorine pesticides and PCBs: Organochlorine pesticides and PCB (aroclor and congener specific) analysis was conducted by Axys Analytical Services LTD., Sidney, B.C., Canada. Organochlorine pesticides and PCBs were analyzed by HRGC/LRMS (High-Resolution Gas Chromatography with detection by Low-Resolution Mass Spectrometry) and GC/ECD (Gas Chromatography with Electron Capture Detection). 
Table 1. Results of Polarized Light Microscopy (PLM) analysis conducted on core sediment samples collected from the Kootenai River, 2007.

\begin{tabular}{|c|c|c|c|c|}
\hline $\begin{array}{l}\text { Sample } \\
\text { Number }\end{array}$ & Sample Appearance & $\begin{array}{c}\% \\
\text { Fibrous }\end{array}$ & $\%$ Non-Fibrous & $\%$ Asbestos (type) \\
\hline TB-1 & Brown, Non-Fibrous, Homogenous & 0 & $100 \%$ Non-Fibrous (other) & None Detected \\
\hline TB-2 & Gray, Non-Fibrous, Homogenous & 0 & $100 \%$ Non-Fibrous (other) & None Detected \\
\hline TB-3 & Gray, Non-Fibrous, Homogenous & 0 & $100 \%$ Non-Fibrous (other) & None Detected \\
\hline TB-3-2 & Brown, Non-Fibrous, Homogenous & 0 & $100 \%$ Non-Fibrous (other) & None Detected \\
\hline TB-5 & Brown, Non-Fibrous, Homogenous & 0 & $100 \%$ Non-Fibrous (other) & None Detected \\
\hline TB-6 & Brown, Non-Fibrous, Homogenous & 0 & $100 \%$ Non-Fibrous (other) & None Detected \\
\hline TB-7 & Brown, Non-Fibrous, Homogenous & 0 & $100 \%$ Non-Fibrous (other) & None Detected \\
\hline TB-8 & Brown, Non-Fibrous, Homogenous & 0 & $100 \%$ Non-Fibrous (other) & None Detected \\
\hline TB-9 & Brown, Non-Fibrous, Homogenous & 0 & $100 \%$ Non-Fibrous (other) & None Detected \\
\hline TB-11 & Brown, Non-Fibrous, Homogenous & 0 & $100 \%$ Non-Fibrous (other) & None Detected \\
\hline TB-12 & Brown, Non-Fibrous, Homogenous & 0 & $100 \%$ Non-Fibrous (other) & None Detected \\
\hline TB-13 & Brown, Non-Fibrous, Homogenous & 0 & $100 \%$ Non-Fibrous (other) & None Detected \\
\hline TB-15 & Brown, Non-Fibrous, Homogenous & 0 & $100 \%$ Non-Fibrous (other) & None Detected \\
\hline TB-16 & Brown, Non-Fibrous, Homogenous & 0 & $100 \%$ Non-Fibrous (other) & None Detected \\
\hline TB-17 & Brown, Non-Fibrous, Homogenous & 0 & $100 \%$ Non-Fibrous (other) & None Detected \\
\hline TB-20 & Brown, Non-Fibrous, Homogenous & 0 & $100 \%$ Non-Fibrous (other) & None Detected \\
\hline TB-21 & Brown, Non-Fibrous, Homogenous & 0 & $100 \%$ Non-Fibrous (other) & None Detected \\
\hline TB-22 & Brown, Non-Fibrous, Homogenous & 0 & $100 \%$ Non-Fibrous (other) & None Detected \\
\hline TB-23 & Brown, Non-Fibrous, Homogenous & 0 & $100 \%$ Non-Fibrous (other) & None Detected \\
\hline TB-231A/1=1 & Brown, Non-Fibrous, Homogenous & 0 & $100 \%$ Non-Fibrous (other) & None Detected \\
\hline TB-231B/1=1 & Brown, Non-Fibrous, Homogenous & 0 & $100 \%$ Non-Fibrous (other) & None Detected \\
\hline TB-23-L & Gray, Non-Fibrous, Homogenous & 0 & $100 \%$ Non-Fibrous (other) & None Detected \\
\hline TB-24 & Brown, Non-Fibrous, Homogenous & 0 & $100 \%$ Non-Fibrous (other) & None Detected \\
\hline
\end{tabular}


Table 2. Results of Transmission Electron Microscopy (TEM) analysis conducted on core sediment samples collected from the middle Kootenai River, 2007. Orange highlighted boxes indicate a sample that contained regulated asbestos fibers. Yellow highlighted boxes indicate a sample that contained unregulated asbestos fibers.

\begin{tabular}{|c|c|c|c|c|c|}
\hline $\begin{array}{c}\text { Sample } \\
\text { Number }\end{array}$ & USGS Sample ID & Asbestos Type & $\begin{array}{c}\text { Number of } \\
\text { Asbestos } \\
\text { Structures } \\
\text { Detected }\end{array}$ & $\begin{array}{c}\text { Analytical } \\
\text { Sensitivity } \\
(\%)\end{array}$ & $\begin{array}{c}\text { Asbestos } \\
\text { Weight } \\
(\%)\end{array}$ \\
\hline TB-1 & 484156116202001 & None Detected & None Detected & 0.01 & $<0.01$ \\
\hline TB-2 & 484141116194901 & None Detected & None Detected & 0.01 & $<0.01$ \\
\hline TB-3 & 484143116194201 & None Detected & None Detected & 0.01 & $<0.01$ \\
\hline TB-3-2 & 484143116194202 & Chrysotile & 1 & 0.01 & 40.01 \\
\hline TB-5 & 484150116192601 & None Detected & None Detected & 0.01 & $<0.01$ \\
\hline TB-6 & 484148116192601 & None Detected & None Detected & 0.01 & $<0.01$ \\
\hline TB-7 & 484154116190301 & None Detected & None Detected & 0.01 & $<0.01$ \\
\hline TB-8 & 484151116191601 & None Detected & None Detected & 0.01 & $<0.01$ \\
\hline TB-9 & 484153116190501 & None Detected & None Detected & 0.01 & 40.01 \\
\hline TB-11 & 484201116184001 & None Detected & None Detected & 0.01 & $<0.01$ \\
\hline TB-12 & 484202116172301 & None Detected & None Detected & 0.01 & $<0.01$ \\
\hline TB-13 & 484202116164501 & None Detected & None Detected & 0.01 & $<0.01$ \\
\hline TB-15 & 484210116153301 & None Detected & None Detected & 0.01 & $<0.01$ \\
\hline TB-16 & 484209116143501 & None Detected & None Detected & 0.01 & $<0.01$ \\
\hline TB-17 & 484234116131901 & None Detected & None Detected & 0.01 & $<0.01$ \\
\hline TB-20 & 484154116120401 & Ferro-Actinolite & N/A & 0.01 & $<0.01$ \\
\hline TB-21 & 484421116242401 & None Detected & None Detected & 0.01 & $<0.01$ \\
\hline TB-22 & 484427116245501 & Ferro-Actinolite & N/A & 0.01 & $<0.01$ \\
\hline TB-23 & $484532116233101(02)$ & None Detected & None Detected & 0.01 & $<0.01$ \\
\hline TB-231A/1=1 & & None Detected & None Detected & 0.01 & $<0.01$ \\
\hline TB-231B/1=1 & & Actinolite & 1 & 0.01 & $<0.01$ \\
\hline TB-23-L & $484532116233101(02)$ & None Detected & None Detected & 0.01 & $<0.01$ \\
\hline TB-24 & 484145116193601 & None Detected & None Detected & 0.01 & $<0.01$ \\
\hline
\end{tabular}




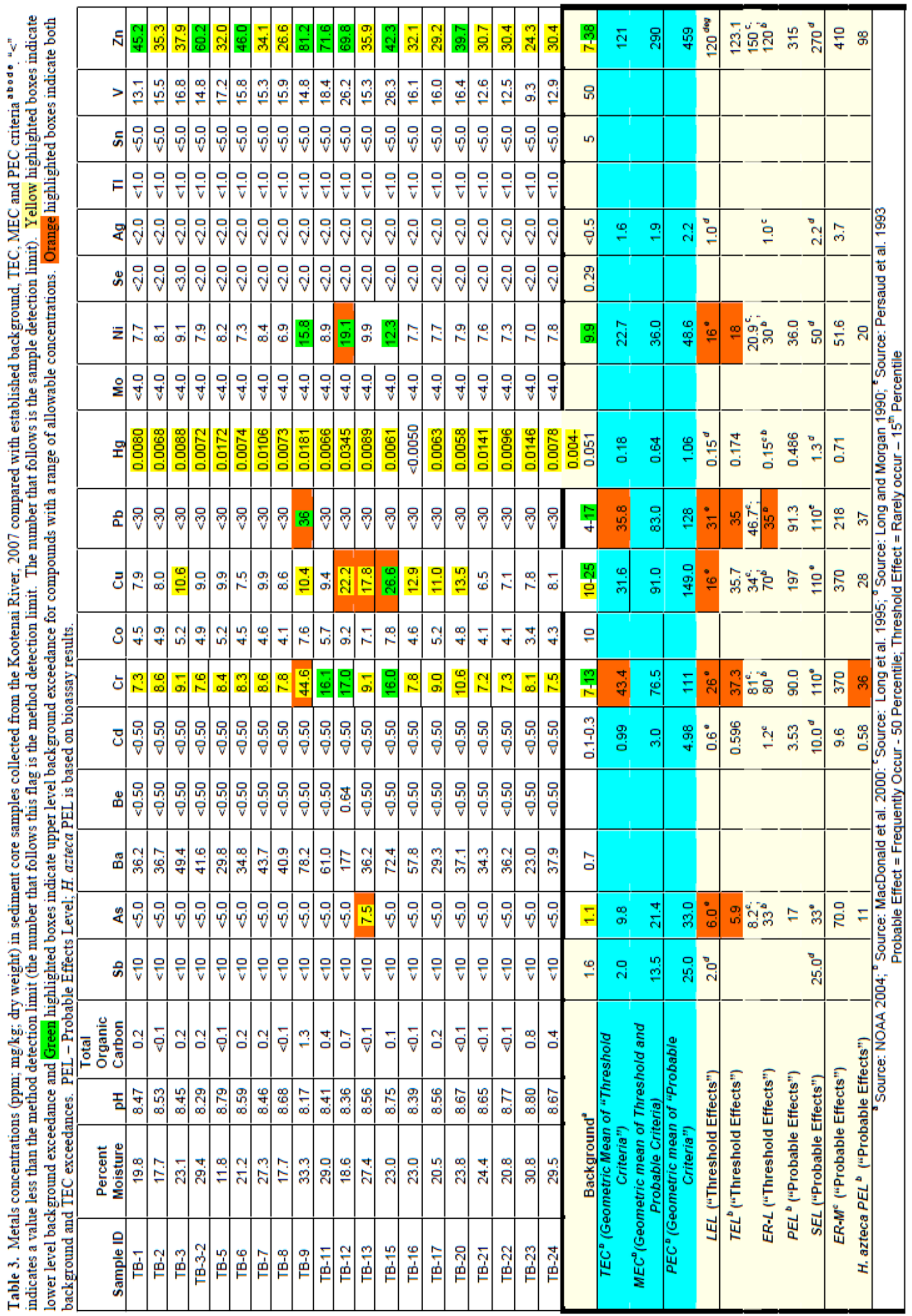


Table 4. Organochlorine concentrations detected in sediment core samples, Kootenai River, Idaho NORMALIZED TO $1 \%$ TOTAL ORGANIC CARBON (detected concentration divided by TOC $\%$ as a whole number). Non-detects are indicated by " $<\mathrm{mdl}$ "; see Appendix 1 for detection limits. Orange highlighted boxes indicate compounds classified as "POPs" (persistent organic pollutants). Green highlighted cells indicate comparative criteria based on $1 \%$ carbon content - blank spaces within green highlighted data indicate lack of established criteria. Yellow highlighted text indicated values that exceed one or more criteria (based on $1 \%$ TOC) in green highlighted section. Pink highlighted text indicates samples with $<0.2 \% \mathrm{TOC}$ - Due to low or below mdl TOC, raw data for these samples were NOT carbon normalized to $1 \%$ TOC.

\begin{tabular}{|c|c|c|c|c|c|c|c|c|c|c|c|c|c|}
\hline \multirow[b]{2}{*}{$\begin{array}{l}\text { Sample } \\
\text { Number }\end{array}$} & \multicolumn{13}{|c|}{ Organochlorine Pesticide Compound (ng/g; ppb dry weight) } \\
\hline & 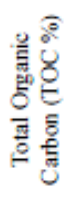 & $\begin{array}{l}\frac{\overline{0}}{\frac{0}{0}} \\
\frac{0}{0} \\
\frac{\bar{y}}{2} \\
\frac{0}{2}\end{array}$ & 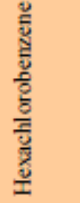 & 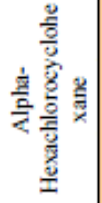 & 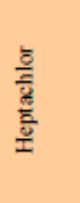 & 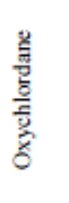 & $\frac{g}{2}$ & $\begin{array}{l}\frac{1}{0} \\
\frac{1}{0} \\
\frac{1}{5}\end{array}$ & 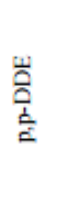 & $\begin{array}{l}\text { Oे } \\
\text { Oे } \\
\text { con }\end{array}$ & $\begin{array}{l}\overline{\hat{0}} \\
\frac{1}{0}\end{array}$ & $\begin{array}{l}\text { 商 } \\
\text { 品 }\end{array}$ & 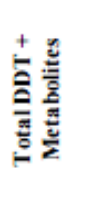 \\
\hline TB-1 & 0.2 & $\begin{array}{l}1.05 \\
\text { (E) }\end{array}$ & mdl & mdl & mdl & mdl & mdl & mdl & mdl & mdl & mdl & $\begin{array}{l}2.500 \\
\text { (E) }\end{array}$ & 2.500 \\
\hline $\begin{array}{l}\text { TB-1 } \\
\text { Duplicate }\end{array}$ & 0.2 & $\begin{array}{l}1.265 \\
\text { (E) }\end{array}$ & mdl & mdl & mdl & mdl & mdl & mdl & mdl & mdl & mdl & $\begin{array}{l}0.220 \\
(\mathrm{E})\end{array}$ & 0.220 \\
\hline IB-2 & 0.1 & $\begin{array}{l}0.100 \\
\text { (E) }\end{array}$ & mdl & mdl & mdl & mdl & mdl & mdl & mdl & mdl & mdl & mdl & 0.000 \\
\hline
\end{tabular}


Table 4 continued. Organochlorine concentrations detected in sediment core samples, Kootenai River, Idaho

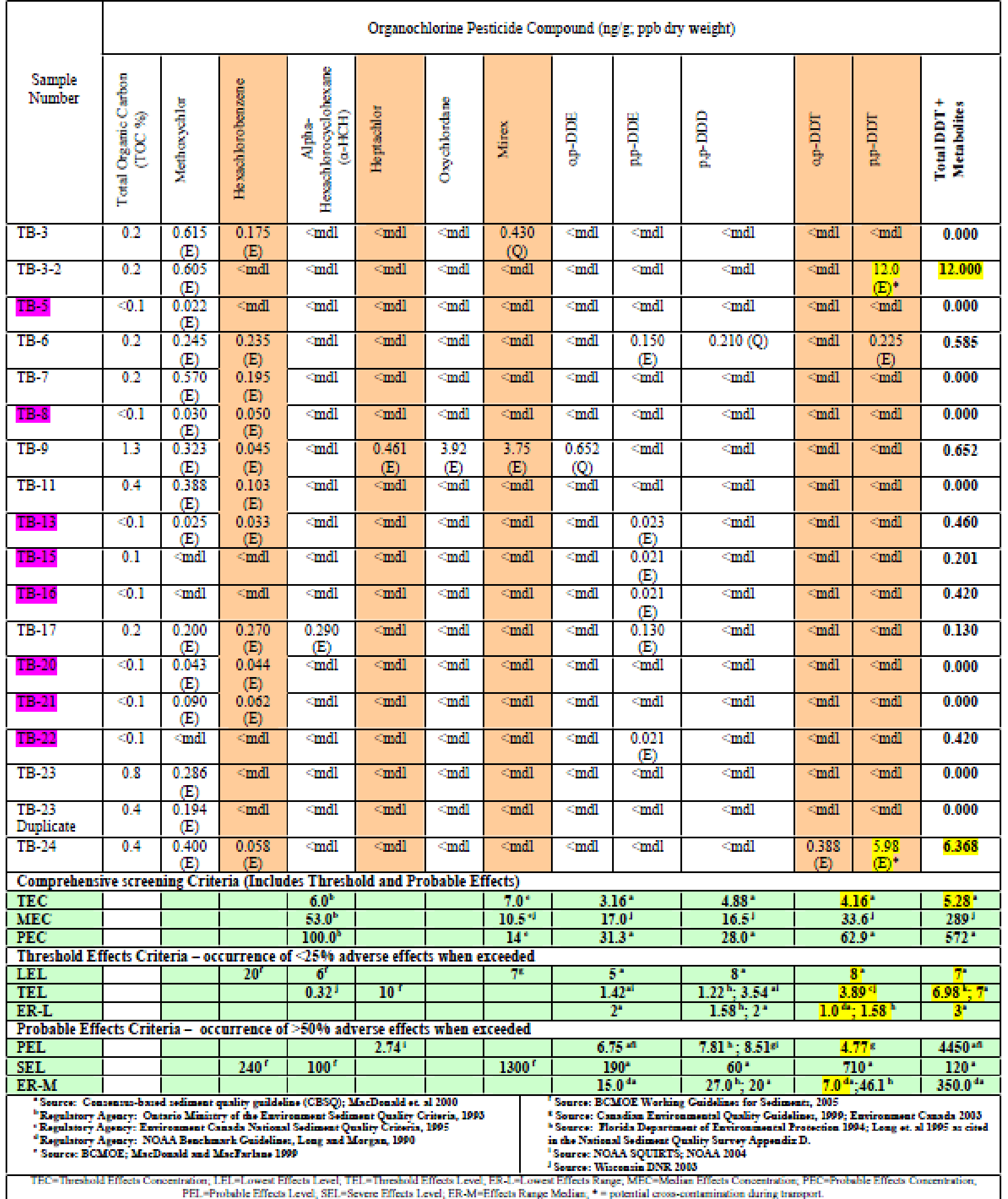


This page intentionally left blank. 
Publishing support provided by the U.S. Geological Survey

Publishing Network, Tacoma Publishing Service Center

For more information concerning the research in this report, contact the

Director, Idaho Water Science Center

U.S. Geological Survey

230 Collins Road

Boise, Idaho 83702

http://id.water.usgs.gov

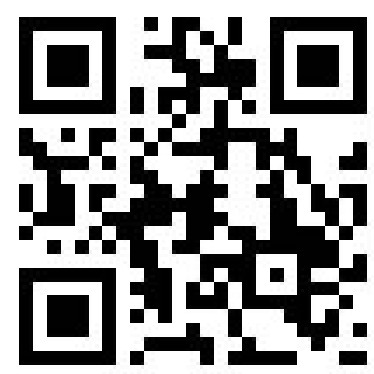




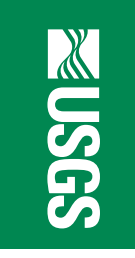

प्ञ⿰冫欠

今ั

웋

里

흘

웅

름

亭

중

疋

音

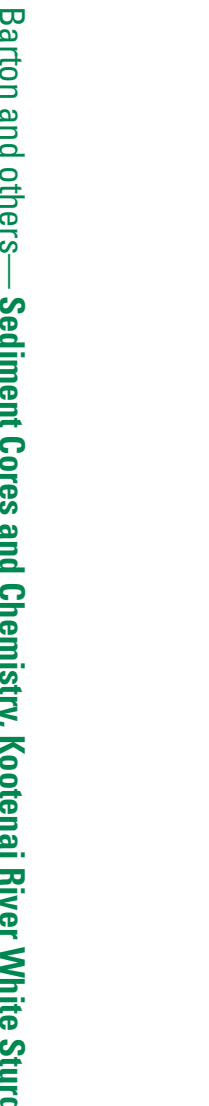

좋

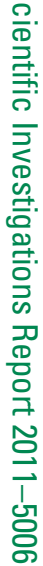

